Historic, Archive Document

Do not assume content reflects current scientific knowledge, policies, or practices. 



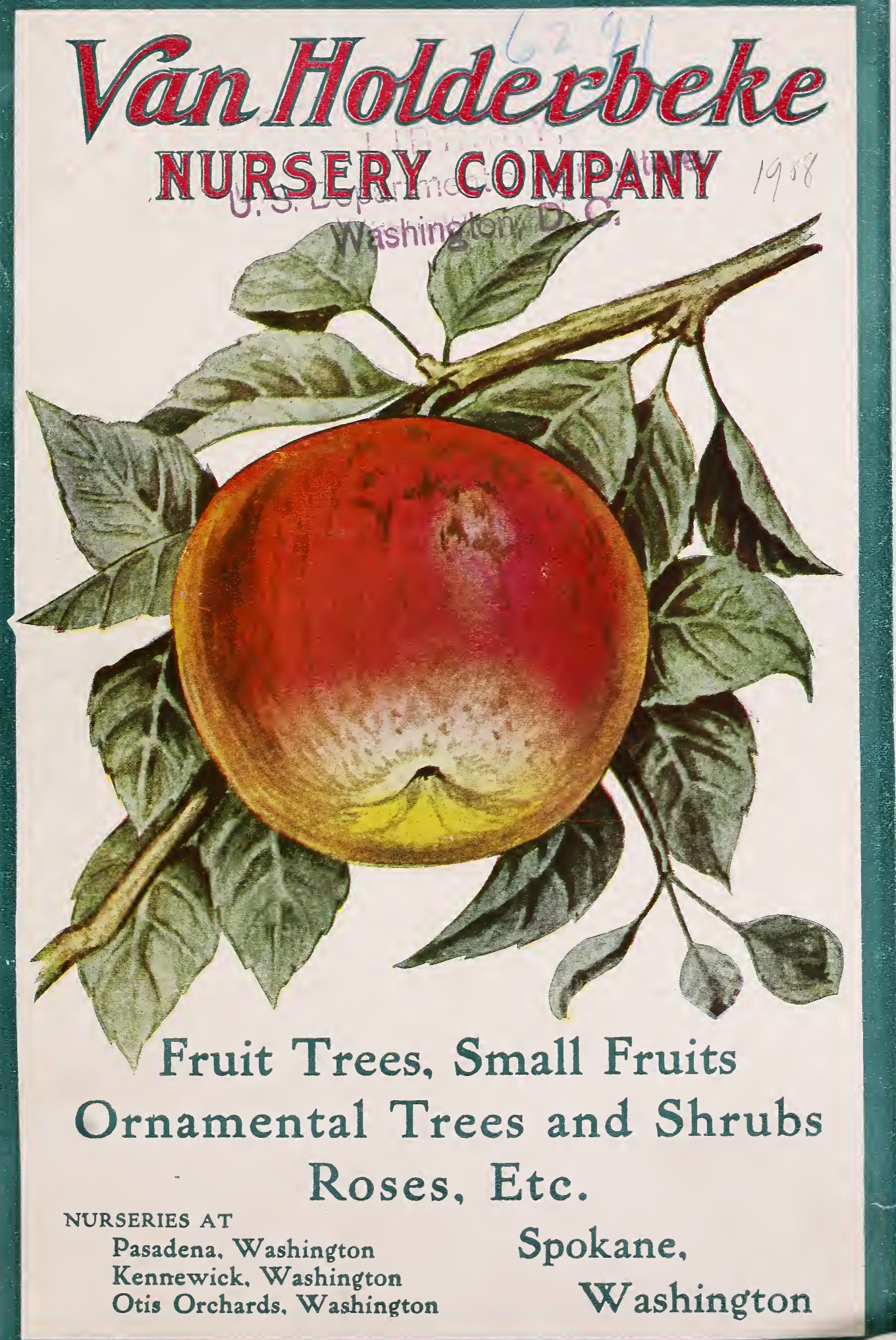


State of WVashington, County of Chelan, ss.

M. Horan, being first duly sworn, on oath deposes and says: That he is the identical person who received first prize on car-load exhibit of apples at the National Apple Show, held at Spokane, Washington, during the fall of 1908; that his orchard is located near Wenatchee, in Chelan County, State of Washington; that A. Van Holderbeke is the only person who cut scions from his said orchard during the fall of 1908 or spring of 1909 or at any time since said Apple Show; and that the said A. Van Holderbeke is the only person authorized to, and he has the exclusive right to cut scions from said orchard. Further affiant sayeth not.

M. HORAN.

Subscribed and sworn to before me this 10th day of June, 1909.

(Seal.)

W. O. PARR,

Notary Public in and for the State of Washington, Residing at Wenatchee in said State. 


\section{Descriptive Catalogue and Price List}

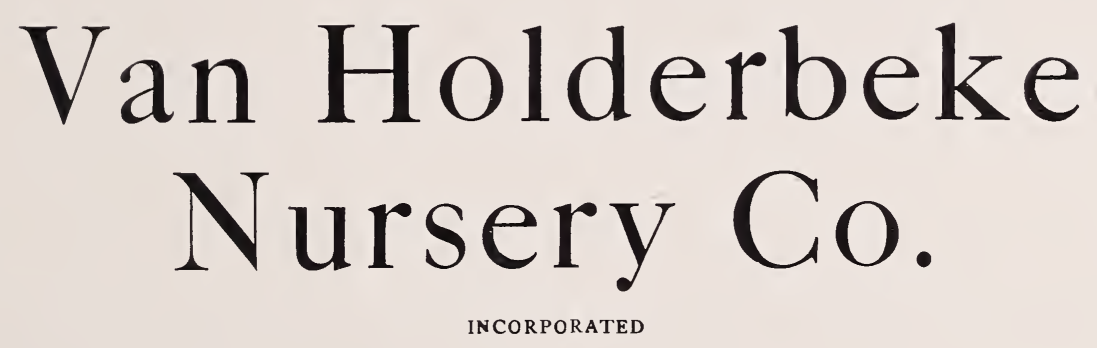

Capital Stock $\$ 60,000.00$

Fully Paid Up

SPOKANE, WASHINGTON

Otis Orchards, Washington

Pasadena, Washington

Kennewick, Washington 
Press of

THE FRLIT-GROWER St Joseph, Mo. 


\section{INTRODUCTION}

We take pleasure in presenting to our patrons and all persons interested in horticulture our second descriptive catalogue, trusting it may be a help to select the right varieties for their orders.

The financial success of an orchard depends entirely on the selection of the right varieties, according to soil, climate, location and market.

Our nurseries consist of all the commercial varieties of apples, pears, peaches, cherries, plums, prunes, grapes, berries, shrubs and flowers. The condition of soil of the nurseries is a sandy loam which, as everybody knows, makes the most perfect root system; consequently the trees will suffer less by the great shock of transplanting.

The nurseries are located near Spokane and Kennewick, the great railroad centers, and this gives us an opportunity to have all shipments delivered with the least possible delay on the road, thus leaving the roots as short a time as possible out of the soil where they naturally belong.

\section{VARIETIES TRUE TO NAME}

A. Van Holderbeke, the president of our nurseries, was graduated from the horticultural departinent of the University of Ghent (Belgium) in 1888 and lectured for several years in that country on horticultural topics. The agricultural year book of the United States of 1896 recognized the horticultural schools of Belgium as the most advanced in horticulture in the world. In $1893 \mathrm{Mr}$. Van Holderbeke left his native land for America and came to the state of Washington, where he has resided ever since, practicing horticulture and making horticultural investigations all over the state. In $1898 \mathrm{Mr}$. Van Holderbeke was appointed horticultural inspector of Snohomish County and occupied that position for three years. In 1901 he received his certificate of qualification as horticulturist from the Washington State College at Pullman. April 1, 1901, Mr. Van Holderbeke was appointed commissioner of horticulture for the State of Washington, which position he held till 1905. His duties as commissioner of horticulture were to investigate horticultural possibilities all over the state, consequently coming in contact with all varieties of fruit and localities, and so he knows by practical experience which are the most successful varieties as to locality and soil.

In propagating by budding or grafting we take one single bud, which grows the future tree. The bud commencing to grow, develops its own leaves enclosed in that bud and those leaves manufacture the perfect plantfood for its kind. Consequently the elements of the whole future tree are enclosed in that bud and it is plain that the whole success of making a perfect tree depends on the selection of scions and buds. We all know that there are experts in every profession, who, by long and careful studies, have reached the high climax of the trade and these same experts we have in horticulture who, through long years of study and experiments, are able to conceive what is enclosed in a bud which is used for propagation and consequently selecting the best buds for the best results.

Mr. Van Holderbeke is selecting all the buds and scions we use in propagating the stock, and as your success is ours, we take every precaution to furnish you the trees of greatest fertility and true to name.

Many fruit-growers invest all their means in planting an orchard and rely upon it for the future welfare of their families. We see in other professions that people 
select; in case of sickness, the best doctor; in case of trouble, the best lawyer; in case of machinery, the best mechanic; in building a house, the best architect. When we consider now the care we use in those other professions, what care should we not use in the selection of nursery stock upon which very often depends the welfare of our families and whole future:

\section{AGE OF TREES}

A one-year-old tree is the best tree for planting for the following reasons, according to plant life: In nature roots and top of a tree are always in equal proportion. In digging a tree in the nursery, the roots are cut off the same length in any age of a tree, and the older the tree, the farther the roots extend. Consequently you cut off more roots of an older tree than of a one-year-old tree, and as root and top always must be in equal proportion, before the tree grows, the top will not grow before the roots have reached the proportions of the top. A one-year-old tree is provided with buds from top to bottom; you may cut the tree back to any height you desire to start your head, and the tree will grow to perfection. An older tree has been cut back in the nursery and started the head according to the notions of a nurseryman, and as the trees stand close together in the nursery row, the heads cannot grow in a symmetrical shape.

The most healthful tree is the most vigorous tree; the one-year-old tree that attains its size is the most vigorous tree and the 2, 3 and 4 -year-old trees sold by nurseries are generally those that do not make vigorous growth. We know that the slower the tree grows the smaller are the cells; the more vigorous a tree grows the larger are the cells and how can you expect a large circulation of sap unless you have large cells?

\section{FALL PLANTING}

According to plant life fall planting is preferable to spring planting. In fall the trees become dormant and by removing at that time, the evaporation of a tree is less than in spring, when buds have swollen and life has started. Consequently a fall planted tree has more plant food to start the roots than a spring planted tree. When the tree is planted in fall, the soil will settle through rain and snow, to its natural solidity, while in spring we do it at a risk; if the condition of the weather is moist, the soil will settle naturally, and if it is dry, it is very hard to do this scientifically, as nature does it.

As soon as wounds are made on a tree and temperature is high enough to heal, perfect plantfood moves to heal the wounds and make new roots. When trees are planted in the fall, the perfect plantfood, in a liquid state in the tree, will more to the wounds of the roots, commence the healing, and roots are ready in spring to start furnishing the buds with plantfood, while the spring planted trees have to make roots first, generally under very unfavorable conditions, as extremes of heat and drought. In fall we have ample time to give all the care to the planting of trees, while in spring we usually are overburdened with work. In fall we have more chances to get better stock from a nursery than in spring, and the assortment in the nursery is more complete in fall than in spring. After planting, bank the soil around the trees from one to two feet high, to prevent damage by frost, rabbits, mice, or the roots loosening by wind.

In conclusion our advice is: Select your trees from such a nursery that has a right to claim a good reputation; select one-year-old trees, grown in your own state, and, if possible, plant in the fall. 


\section{Treatment of Stock, Planting Directions, Etc.}

\section{WINTERING TREES WHEN PROGURED IN THE FALL}

Procuring trees in the autumn for early spring planting is recommended when the purchaser is not prepared to plant in the fall or prefers spring setting; the greatest advantages derived in doing so are that when the roots have been cut or pruned, it will be found, upon taking them up in the spring, that a callous has been formed ready ior the producing of new rootlets, and the trees being planter without much exposure, as soon as the frost is out of the ground, will become thoroughly established the first season, and should make twice the growth of late planted trees; and the labor of planting is then done before the rush of the spring work sets in. To insure success, select a dry spot of ground where water will not stand during winter and no grass or litter will invite mice. Dig a trench from three to four feet wide, according to the amount of trees to be heeled in, and deep enough to admit one layer of roots and sloping enough to let the trees lie at an angle of about thirty degrees, throwing the earth on the back part of the trenches so as to make a more perfect slope on which to lay down the trees. Untie each bundle, shake out the packing, put one layer of trees into the trench, placing the routs as close together as can conveniently be done; cover with well pulverized soil well up on the bodies and as carefully worked in about the roots as if they were being planted; then add another layer of trees, overlapping the first, and continue as at first until all are heeled in, throwing the ground well up around the trench, and where the winters are very severe it is advisable to cover the trees entirely with earth. Evergreen boughs, coarse straw or corn fodder can be placed over the tops, but not thick enough to admit of a harbor for mice. The roots should be pruned before laying them down in the fall.

\section{TREATMENT OF STOCK RECEIVED DURING FROSTY WEATHER}

Place the package, unopened, in a cool cellar, or some such place, that is free from frost, until perfectly thawed. Don't be in a hurry to open. Stock can remain in this condition for a week or two, if boxes are covered with moss, sawdust, earth or something to exclude air. Then they can be unpacked. Treated thus, they will not be injured by freezing.

\section{HINTS ON TRANSPLANTING, ETC.}

The natural place for the roots of trees and plants is in the ground, and as soon as they are exposed to the atmosphere and become too dry they begin to lose their vitality; therefore, let it be kept in mind that too much care cannot be taken to protect their life and vitality while out of the ground, as a failure in this is often the cause of a feeble growth when transplanted. Poor growth is also caused by not having the ground in proper condition at time of transplanting and a lack of after-cultivation.

When the trees are received, open the bundles and heel in, so that mellow earth will come in contact with all the roots. It may be necessary to apply water to moisten the soil. Before planting, the ends of all bruised and broken roots must be cus. If the soil is properly prepared the holes need not be dug much larger than to receive the roots in their original position. Never cramp or bend the roots, rather cut them back. 
In planting in sod, in yard or lawn, the hole should be dug four to six feet in diameter and a little deeper than is necessary to set the tree, always using good mellow soil in filling in.

Water freely used in planting helps to settle the earth about the roots and mulching as soon as the tree is planted, three or four inches thick and four to six feet in diameter, should be applied, but the earth should be well settled about the tree before applying the mulching. On irrigated land give the trees a good watering after planting and cultivate the next or overnext day.

Cut tops back right after planting in spring to the desired height; low heads are best. On fall planted trees it is advisable to cut the tops back only the following spring, before the growth starts.

Remove labels or wire will cut into the growing tree and ruin it.

DEPTH TO PLANT-About the only correct guide that can be given in regard to the depth to be planted is that when the ground is well settled about the tree or plant it will be as deep or a little deeper than it stood in the nursery.

\section{NUMBER OF TREES OR PLANTS ON AN ACRE AT GIVEN DISTANGES APART}

$\begin{array}{cr}\text { Number of Plants } \\ \text { Square } & \begin{array}{c}\text { Equilateral } \\ \text { Triangle } \\ \text { Method }\end{array} \\ 43,560 & 50,300 \\ 10,890 & 12,575 \\ 4,840 & 5,899 \\ 2,722 & 3,143 \\ 1,742 & 2,011 \\ 1,210 & 1,397 \\ 888 & 1,035 \\ 680 & 785 \\ 537 & 620 \\ 435 & 502 \\ 302 & 348 \\ 222 & 256 \\ 193 & 222 \\ 170 & 191 \\ 134 & 154 \\ 109 & 125 \\ 69 & 79 \\ 48 & 55 \\ 35 & 40 \\ 27 & 31 \\ & \end{array}$

\section{Distance}

1 foot apart each way

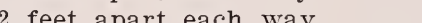

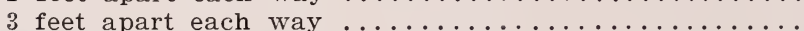

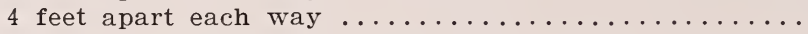

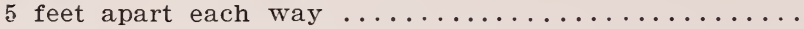

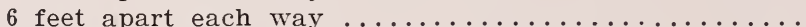

7 feet apart each way

8 feet apart each way

9 feet apart each way

10 feet apart each way

12 feet apart each way

14 feet apart each way

15 feet apart each way

16 feet apart each way

18 feet apart each way

20 feet apart each way

25 feet apart each way

30 feet apart each way

35 feet apart each way

40 feet apart each way $\ldots \ldots \ldots \ldots \ldots \ldots \ldots \ldots$

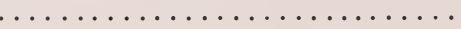

$\ldots \ldots \ldots \ldots \ldots \ldots \ldots \ldots \ldots \ldots \ldots \ldots$

$\ldots \ldots \ldots \ldots \ldots \ldots \ldots \ldots \ldots \ldots$

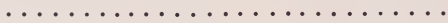

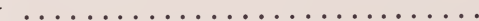

Rule, Square Method-Multiply the distance in feet between the rows by the distance the plants are apart in the rows, and the product will be the number of square feet for each plant or hill, which, divided into the number of square feet in an acre $(43,560)$, will give the number of plants or trees to the acre.

Rule, Equilateral Triangle Method-Divide the number required to the acre, "square method," by the decimal .866. The result will be the number of plants required to the acre by this method.

\section{DISTANCES FOR PLANTING}

Standard Apple ........................... to 30 feet apart each way Standard Pears .................................. to 25 feet apart each way Strong Growing Cherries .................20 to 25 feet apart each way Duke and Morello Cherries .................. to 18 feet apart each way Standard Plums and Prunes ................ to 18 feet apart each wav Apricots, Peaches and Nectarines .............16 to 18 feet apart each way

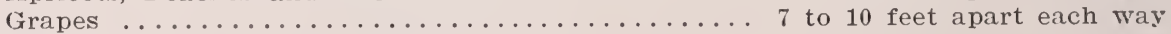
Currants and Gooseberries .............................. 4 by 6 Raspberries and Blackberries .................... 4 to 4 by 5 to 7 Strawberries for field culture ................... 1 to $1 \frac{1 / 2}{2}$ by 4 to 4 Strawberries for garden culture ................... 1 to 2 feet apart 


\section{APPLES}

One-year-old Grafted and Budded Stock.

First grade, 4 to 6 feet high $\ldots \ldots \ldots \ldots \ldots \ldots \ldots \ldots \ldots \ldots \ldots \ldots \ldots \ldots \ldots$

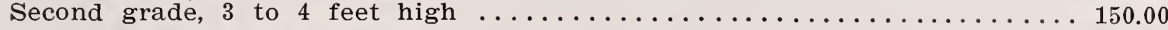

Third grade, under 3 feet high $\ldots \ldots \ldots \ldots \ldots \ldots \ldots \ldots \ldots \ldots \ldots \ldots \ldots \ldots$

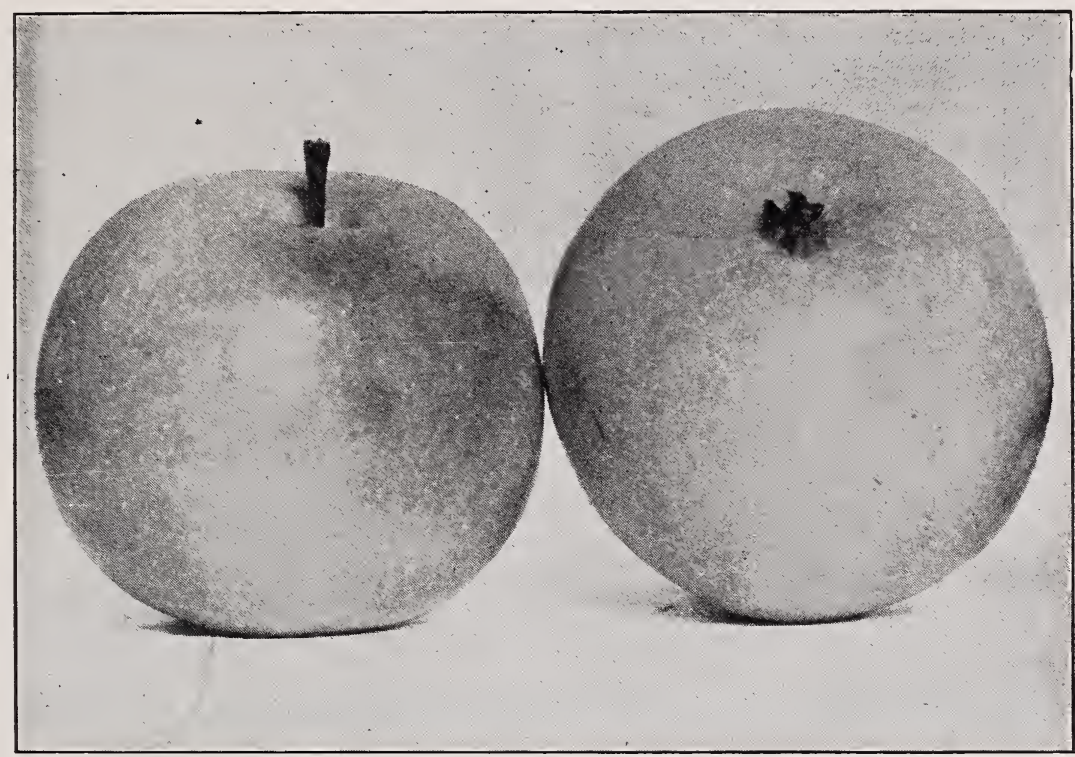

Yellow Transparent

\section{SUMMER VARIETIES}

DUCHESS OF OLDENBURG-Large, striped red, tree hardy, good bearer, good cooking apple, flavor sprightly, sub-acid.

RED JUNE-Vigorous, abundant bearer, greenish-yellow covered with red, tender. juicy, very good.

EARLY HARVEST-Medium to large, yellow, flesh white, tender, juicy and crisp. YELLOW TRANSPARENT-Tree upright, hardy, early bearer, yellow, acid, good. RED ASTRACHAN-Tree hardy and good bearer. Fruit juicy and acid; dark crimson.

\section{FALL VARIETIES}

ALEXANDER-Large, red, flesh yellowish-white, tender, crisp; one of the finest fall apples.

GRAVENSTEIN-Old and widely known, vigorous, productive, large; striped, fine quality.

GRIMES' GOLDEN-Medium to large, golden-yellow, flesh yellow, tender, juicy and'spicy; highly recommended.

JEFFERIS-Medium, striped, splashed and marbled, red, tender, juicy, rich, mild sub-acid flavor. 


\section{APPLES-Continued}

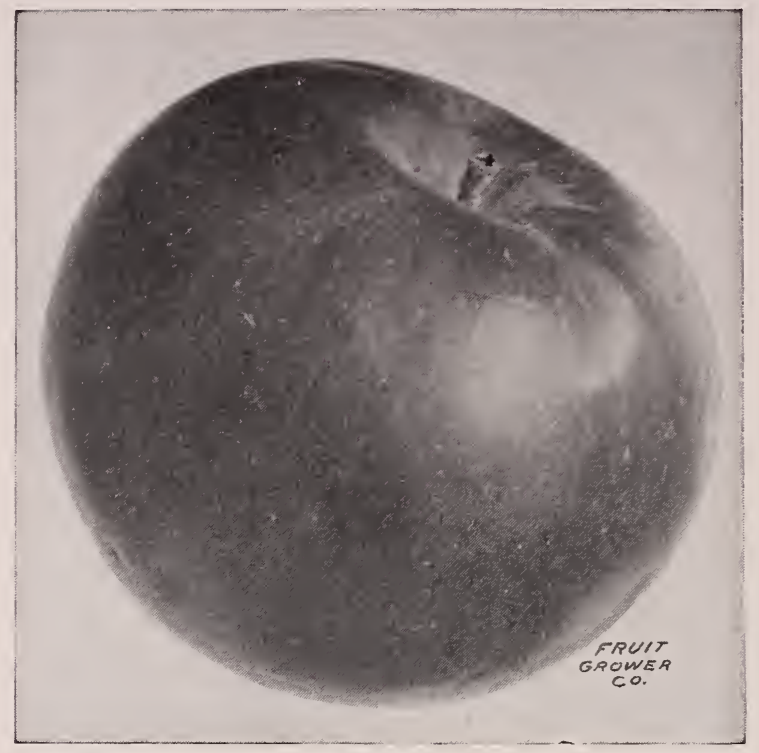

MAIDEN BLUSH - Medium, tree vigorous, color yellow with red cheek. tender, juicy, rich, tender, sprightly, sub-acid.

RED McINTOSH - Large. nearly covered with red. very good flavor, subacid.

NORTHERN SPY-Large, round, greenish - yellow. with purplish-red stripes, juicy, sub-acid.

RHODE ISLAND GREEN I N G - Large, yellow, abundant bearer, tender and juicy.

SNOW (Fameuse)-White. striped red, flesh very white and juicy; very good and widely known.

WEALTHY_Fine appearance and quality; early and abundant bearer, red streaked with white.

WOLF RIVER-Very large, yellow with red stripes and splashes, acid.

YELLOW BELLFLOWER-An old favorite; yellow slightly blushed, flesh yellow, tender, juicy and fine flavor.

RAMBO-Streaked yellow and red, flesh yellowish-white, tender, rich, sub-acid

\section{WINTER VARIETIES}

BLACK BEN DAVIS-Resembles Gano and Ben Davis, but better in quality; solid, rich red, long keeper.

JONATHAN - One of the best commercial varieties, medium size, color rich red, crisp, juicy, finest flavor.

KING-Large and beautiful, red and yellow, good quality.

OLYM PIA BALDWIN-Seedling of King and Baldwin, tree vigorous grower, fruit dark red, fine flavor, good keeper. best commercial variety for high altitudes.

ROME BEAUTY - Large, yellow with red stripes, b e a u t iful appearancr, very productive, subacid; one of the finest market apples. See cover page.

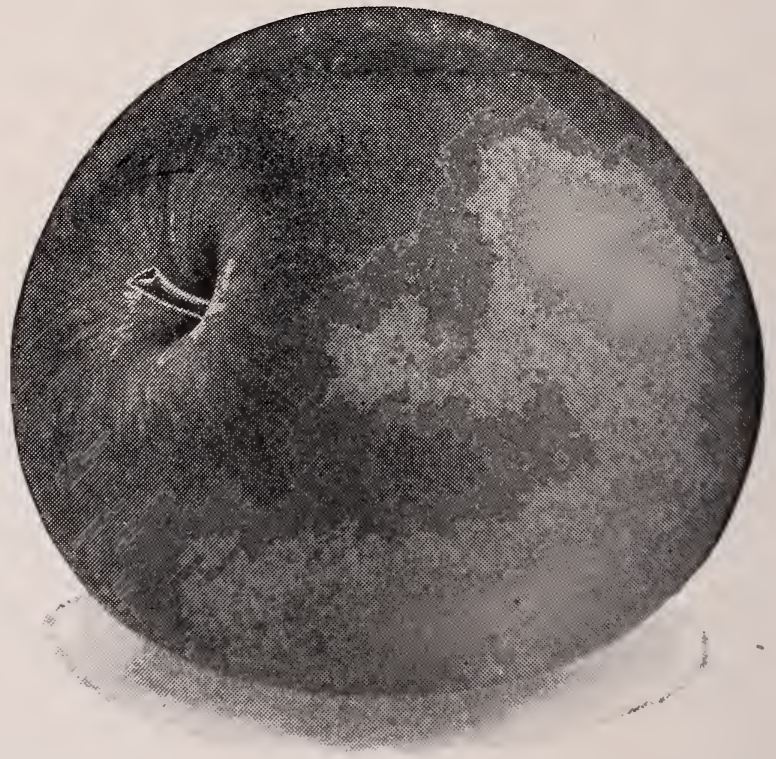

Jonathan 


\section{APPLES-Continued}

SPITZENBURG (Esopus)-Mediunı to large, crisp, sub-acid, finest flavor, color deep red, alway's commands highest prices.

STAYMAN WINESAP-Large, dark red, sub-acid, productive, good keeper, tre? vigorous.

WAGENER-One of the best and most profitable commercial varieties; highly recommended, bright red, flesh crisp, juicy and fine flavor, long keeper, early bearer, excellent.

WHITE WINTER PEARMAIN-Medium to large, round, yellow, high flavor, long keeper, attracts more attention every year; very profitable.

WINESAP-One of the leading varieties, medium to large, fine, dark red, sub-acid, excellent flavor, long keeper, money maker.

WINTER BANANA-Large, yellow with red cheeks, juicy, tender, with banana flavor, attracts much attention, commands high prices.

YELLOW NEWTOWN PIPPIN-Another leading variety, highest quality, highest prices, yellow, very firm, juicy, delicious flavor, long keeper.

STAR NO 1-Resembles Delicious.

STAR NO. 2 - Resembles $\mathrm{K}$ i n g David.

\section{NEW! NEW!}

OTIS SPITZENBURG-New variety of the Spitzenburg family surpassing Spitzenburg greatly in fertility; cross between Yellow Bellflower and Esopus Spitzenburg; tree very vigorous, heavy bearer, fruit red as Spitzenburg. a little uneven as Bellflower, flavor rich, juicy, aromatic, best to eat from December until April: highest quality, highest prices.

Price- $\$ 1$ each; $\$ 10$ per dozen: $\$ 50$ per 100 .

\section{CR AB APPLES}

TRANSCENDENT - Medium, red and yellow, profitable for market. excellent for cooking, jelly and

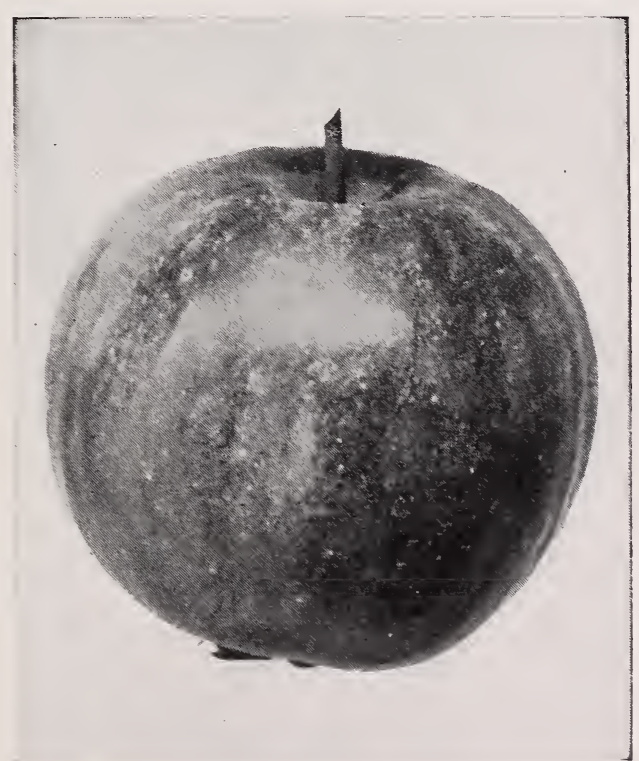

Transcendent cider.

RED SIBERIAN-Yellow with scarlet cheeks, grows in clusters, young and abundant bearer.

WHITNEY'S NO. 20-Large; splashed with carmine; flesh firm, juicy and rich; a great bearer and very hardy. Tree a vigorous, handsome grower. Has no superior, if an equal. August. 


\section{PEARS}

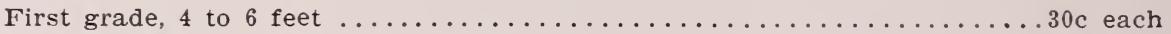

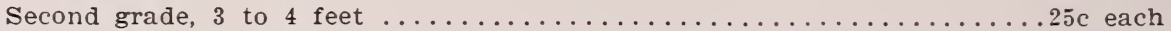

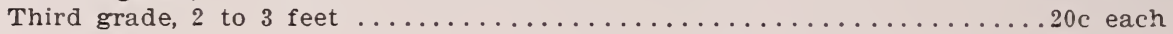

BARTLETT--Best known and most popular pear, fine grower and good bearer; everybody should plant it.

BEURRE d'ANJOU-Large, buttery and melting, sprightly, fine flavor; one of the best.

BEURRE CLAIRGEAU-Very large, yellow and red, tree vigorous, abundant bearer, highly flavored.

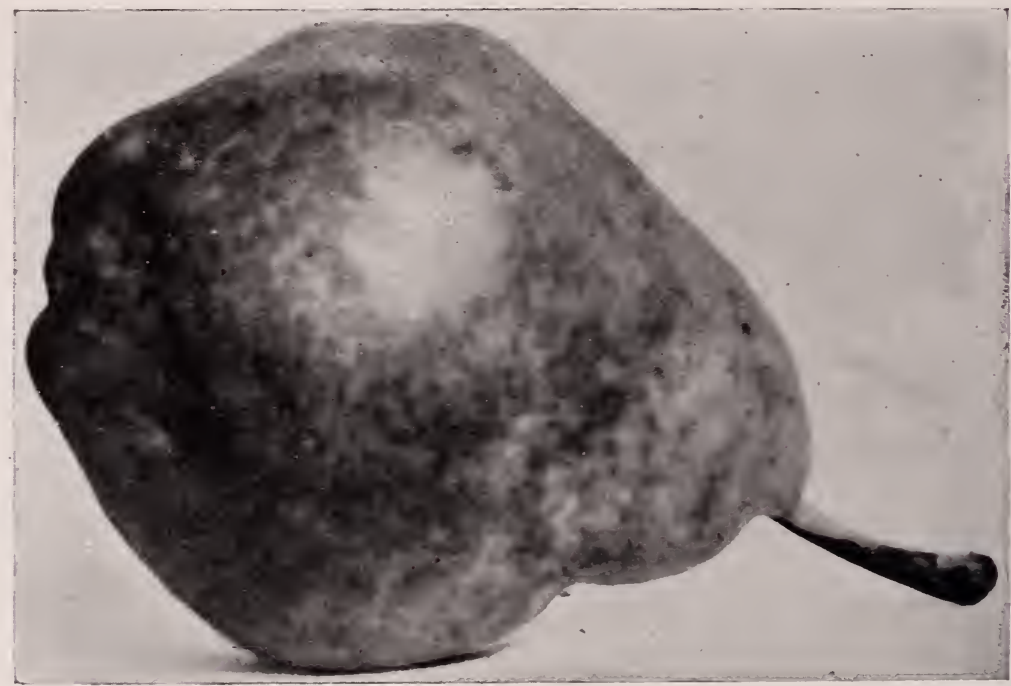

Bartlett

CLAPP'S FAVORITE-Very early, large, juicy and delicious, yellow with red cheeks; ought to be picked about ten days before ripe.

COMICE-Very large, good keeper, fine flavor, always commands high prices.

FLEMISH BEAUTY_Large, juicy, melting, rich, tree hardy and vigorous and bears. abundantly.

SECKEL-Small but of delicious flavor and highest quality, yellow and red.

SUGAR PEAR-Medium early, good pear, abundant bearer.

ROSSNEY-Hardy, vigorous grower, very productive; ripens two weeks after Bartlett; good keeper, skin creamy with crimson blush, flesh melting, juicy, sweet and of finest flavor; Burbank says it is the best pear so far seen. 


\section{CHERRIES}

First grade, 4 to 6 feet ................. 40 c each

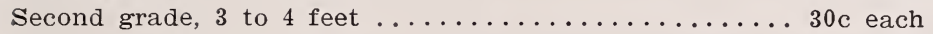

\section{SWEET VARIETIES}

BING-Very large, dark, almost black, firm, rich and delicious; best shipper and most profitable.

HOSKINS - One of the best, very large, dark.

LAMBERT - Very large, best shipper, dark red, roundish. heart-shaped, flavor rich.

ROYAL ANN - Yellow with bright red cheeks, flesh firm, juicy and sweet, excellent for market and canning.

\section{SOUR VARIETIES}

MAY DUKE-Large, dark red, juicy.

LATE DUKE-Large, light red, juicy, the productive old sort.

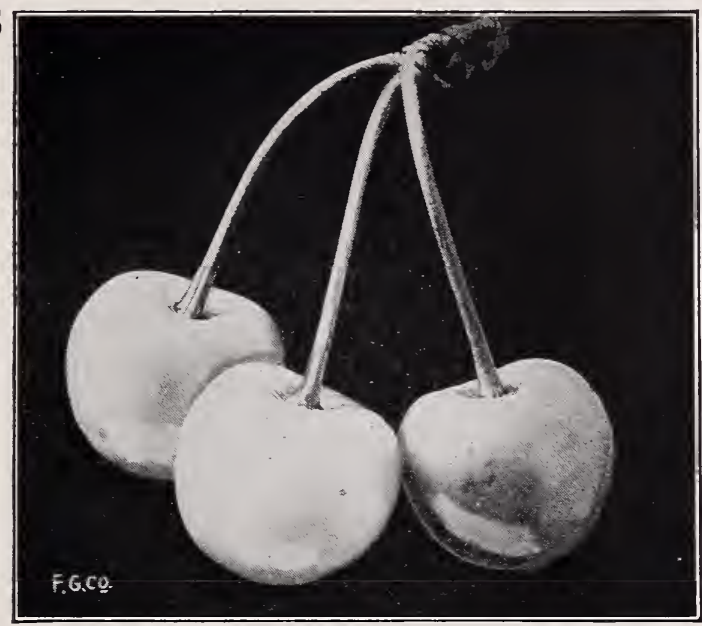

Royal Ann

EARLY RICHMOND-Medium size, red, juicy, sprightly, acid, very popular; trees hardy; best for canning.

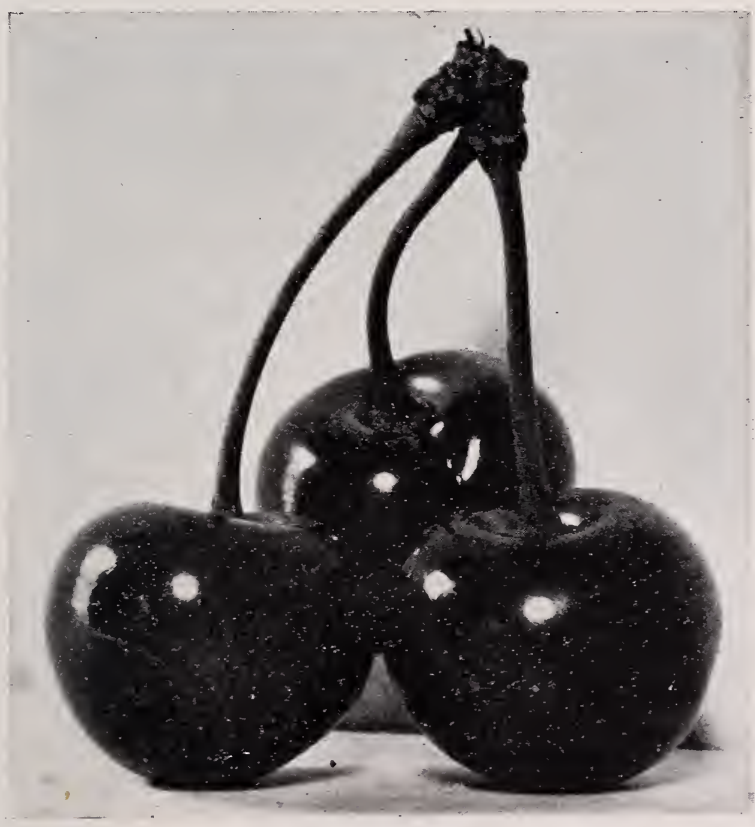

Montmorency
M ONT M O RENCY Tree very hardy and an immense bearer; commences to fruit while young, and is loaded annually thereafter with fine crops. Fruit very large, fine flavor and of bright, clear, shining red: valuable everywhere: a week later than Early Richmond. The finest acid cherry.

MORELLO, ENGLISH -Large, dark red, nearly black; tender, juicy, acid, rich. Tree dwarf and slender.

\section{QUINCES}

$50 \mathrm{c}$ each.

PINEAPPLE-Delicious pineapple flavor.

ORANGE-Best of the old varieties.

CHAMPION - La r g e, late ripening. 


\section{PEACHES}

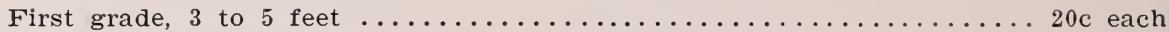

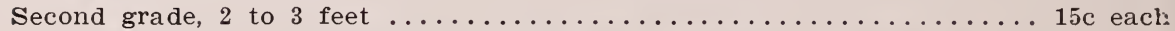

ALEXANDER-Early and popular, medium to large, pale green, mostly covered with red, flesh white, tender and juicy; clingstone.

EARLY CRAWFORD - Large, red and yellow, freestone, good quality and very productive.

LATE CRAWFORD-Similar to Early Crawford, but ripens about four weeks later.

ELBERTA - Very large, freestone, bright yellow with red. flesh yellow; fine sort for market.

FOSTER - Ripens after Early Crawford, flesh yellow, rich and juicy, large, dark orange. red.

OCTOBER KRUMMEL - Late, large, almost round, dark yellow with dark red blush, flesh yellow, firm, melting, sub-acid, very valuable for market.
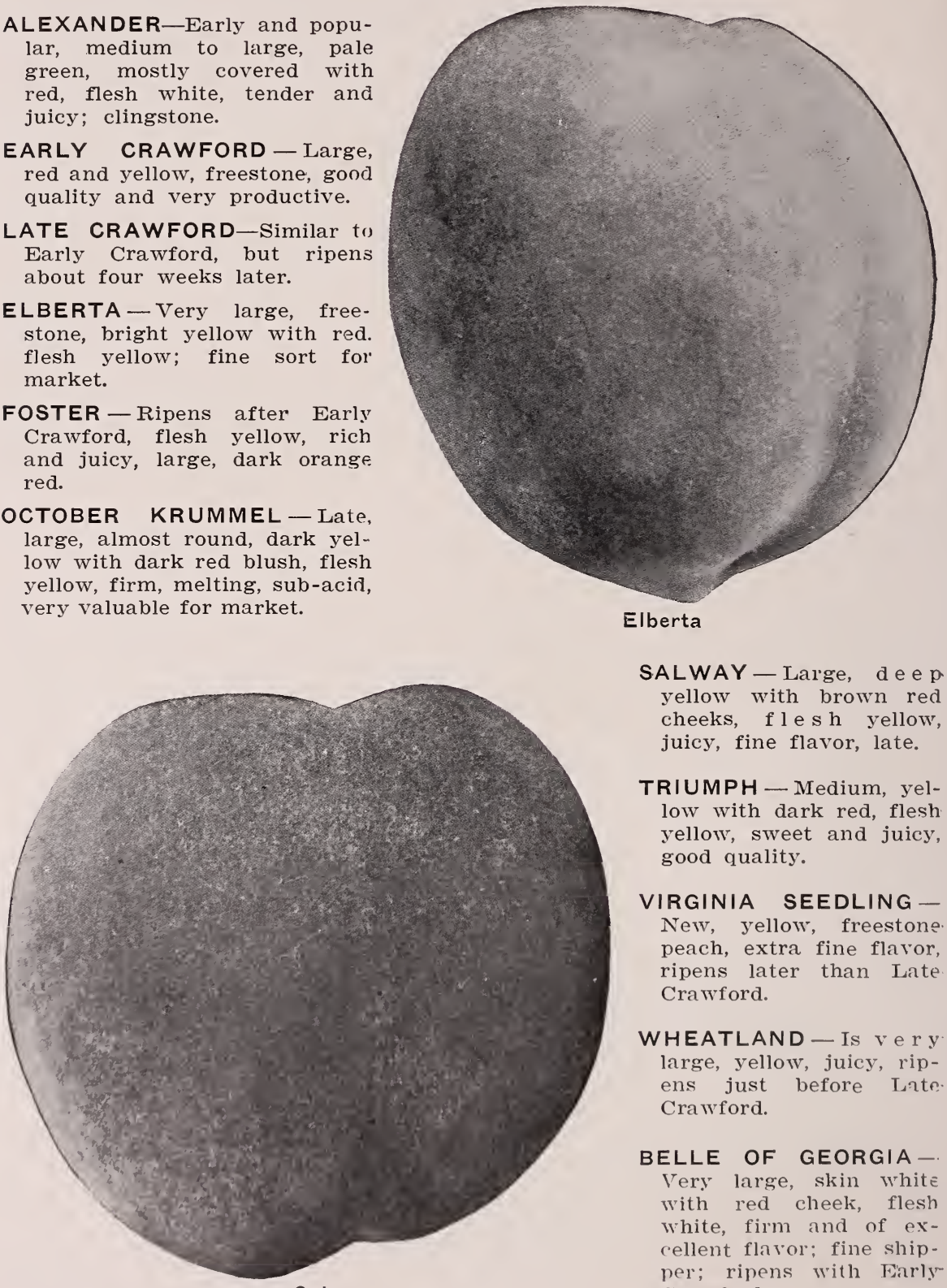

SALWAY - Lalge, de e p yellow with brown red cheeks, flesh yellow, juicy, fine flavor, late.

TRIUMPH - Medium, yellow with dark red, flesh yellow, sweet and juicy, good quality.

VIRGINIA SEEDLING New, yellow, freestone. peach, extra fine flavor, ripens later than Late. Crawford.

WHEATLAND - Is ve ry large, yellow, juicy, ripens just before Late. Crawford.

BELLE OF GEORGIA-. Very large, skin white with red cheek, flesh white, firm and of excellent flavor; fine shipper; ripens with Farly crawford. 


\section{APRICOTS}

First grade, 4 to 6 feet............................... 20. each

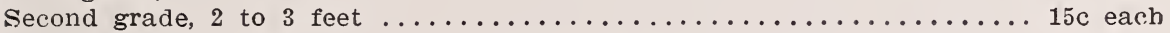

MOORPARK-Very large, orange with red, sweet; one of the best.

ROYAL_Large, oval, yellow and red.

\section{PLUMS AND PRUNES}

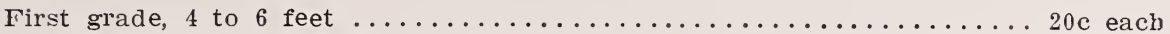

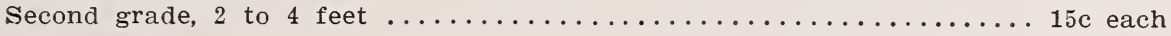

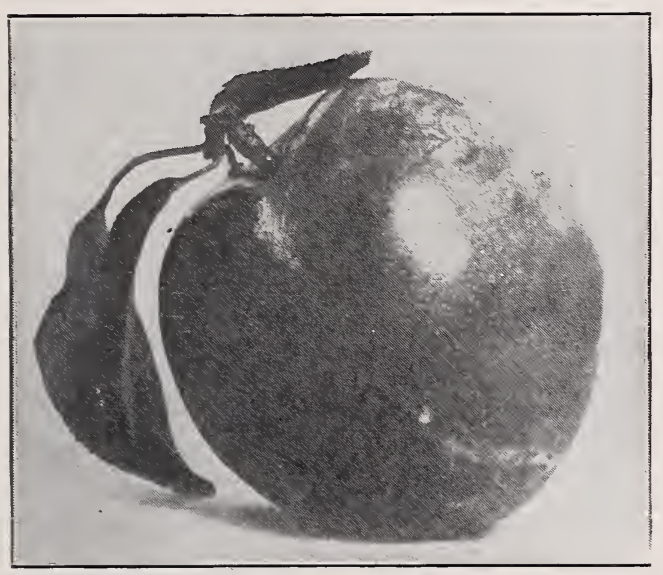

Bradshaw
BRADSHAW-Large, purple, flesh greenish-yellow, rich.

CLIMAX-Vigorous and productive; fruit large, dark red, sweet, finest flavor; early.

GOLDEN DROP - Very early, small, bright yellow, sweet.

HUNGARIAN-Large, bright red, good bearer and shipper.

ITALIAN - Large, oval, purple, sweet, best for drying, juicy and delicious.

PEACH PLUM-Large, early, red, widely known.

PETITE-Medium, reddish purple. sweet and juicy, immense bearer.

SILVER-Tery large, one of the best prunes and drying plums.

SUGAR - Very large, dark red, flesh yellow, tender, sugary.

TRAGEDY-Medium, dark purple, flesh yellowish-green, very sweet and rich; early. YELLOW EGG-Very large, yellow skin and flesh.

\section{MULBERRIES}

The Mulberry furnishes the two-fold purpose of ornamental and fruit tree. It is easily cultivated, and requires iittle or no pruning. It does best planted in a deep, sandy loam and warm situations.

DOWNING'S EVERBEARING-Tree only obtains moderate size, but is very vigorous and productive, continuing in bearing a long time; fruit $1 \frac{1}{4}$ inches long, and $3 / 8$ of an inch in diameter; color blue black; flesh juicy, rich, sugary, with a sprightly, vinous flavor. 4 to 6 feet, $60 \mathrm{c}$.

RUSSIAN-A very hardy, rapid growing timber tree of great value, introduced from Russia by the Mennonites; foliage abundant. Fruit smaller than the Downing; but otherwise similar. 4 to 6 feet, $30 \mathrm{c}$. 


\section{NUT TREES}

\section{ALMONDS}

$35 \mathrm{c}$ each.

IXL-Tree a sturdy, rather upright grower; nuts large; hulls easily; shell soft but perfect.

THE JORDAN - The nuts are long and are hardshells; the kernels are single, narrow, long and plump. The tree is a strong, thrifty grower and heavy bearer. A most excellent variety; prized as the most delicious nut.

NONPAREIL-Of a weeping style of growth, but still forms a beautiful tree; an extraordinarily heavy and regular bearer, with very thin shell; of the Paper Shell type.

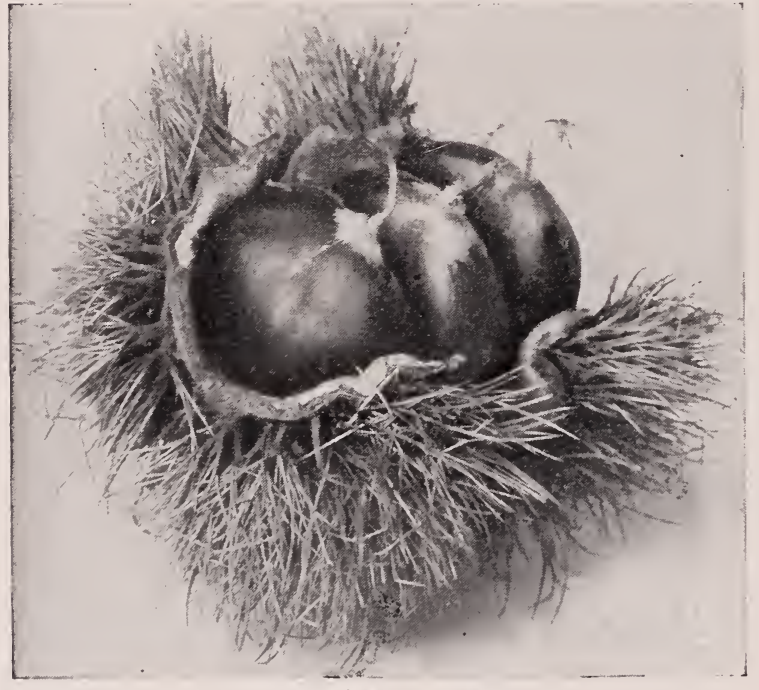

American Sweet

\section{CHESTNUTS}

2 to 3 feet; each, $45 \mathrm{c}$.

AMERICAN SWEETWherever soil is adapted to its growth; valuable for ornament, timber and nuts.

SPANISH OR ITALIANA handsome, round headed tree, producing abundantly very large nuts that find a ready market at good prices. Not quite as sweet as the American Chestnuts. Tree is hardy with us.

\section{WALNUTS}

AMERICAN BLACK-This valuable tree grows and succeeds well on this coast. Valuable for timber and nuts. 2 to 3 feet, $30 \mathrm{c}$.

BUTTERNUT OR WHITE WALNUT-A fine native tree, producing a large, longish nut, which is prized for its sweet, oily, nutritious kernel; tree hardy; 3 to $4 \mathrm{ft}$., $40 \mathrm{c}$.

\section{ENGLISH WALNUTS}

From 2 to 3 feet, $50 \mathrm{c}$ each. $\$ 40.00$ per 100 .

FRANQUETTE-Large, oval, very attractive; kernel full-fleshed and sweet. MAYETTE-Fine, large dessert nut.

PREPARTURIEN-Perfect, soft shelled, fine quality and very productive. 


\section{GRAPES}

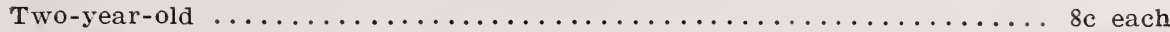

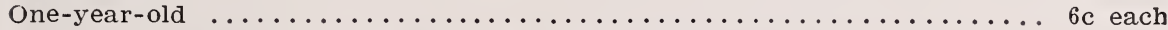

CAMPBELL'S EARLY-Something new, great bearer and shipper, flavor rich and sweet, large round berries. $12 \mathrm{c}$ each.

CONCORD-The fine old leader; everybody knows it.

DELAWARE - Skin thin, light red, very sweet, juicy and spicy; berries rather small and round.

MOORE'S EARLY - Berries large, round, black, early and hardy.

NIAGARA-Best white variety, large.

WORDEN - Said to be a seedling of Concord, but larger berries, better flavor and earlier.

\section{FOREIGN VARIETIES}

BLACK HAMBURG-Berries black, very large and long, especially good for table.

MALAGA - Greenish-yellow, very large, juicy grape, grown in Spain for exportation.

MUSCAT - Greenish-yellow, very large and juicy, spicy flavor.

ROSE OF PERU-Large, strong $\mathrm{grow}$ er, large bunches.

ROUMANIA - Very large, black, new variety.

TOKAY - Large, thick skin, pale red, sweet.

SWEETWATER-Medium, thin skin, greenish-yellow, rich and sweet, early.

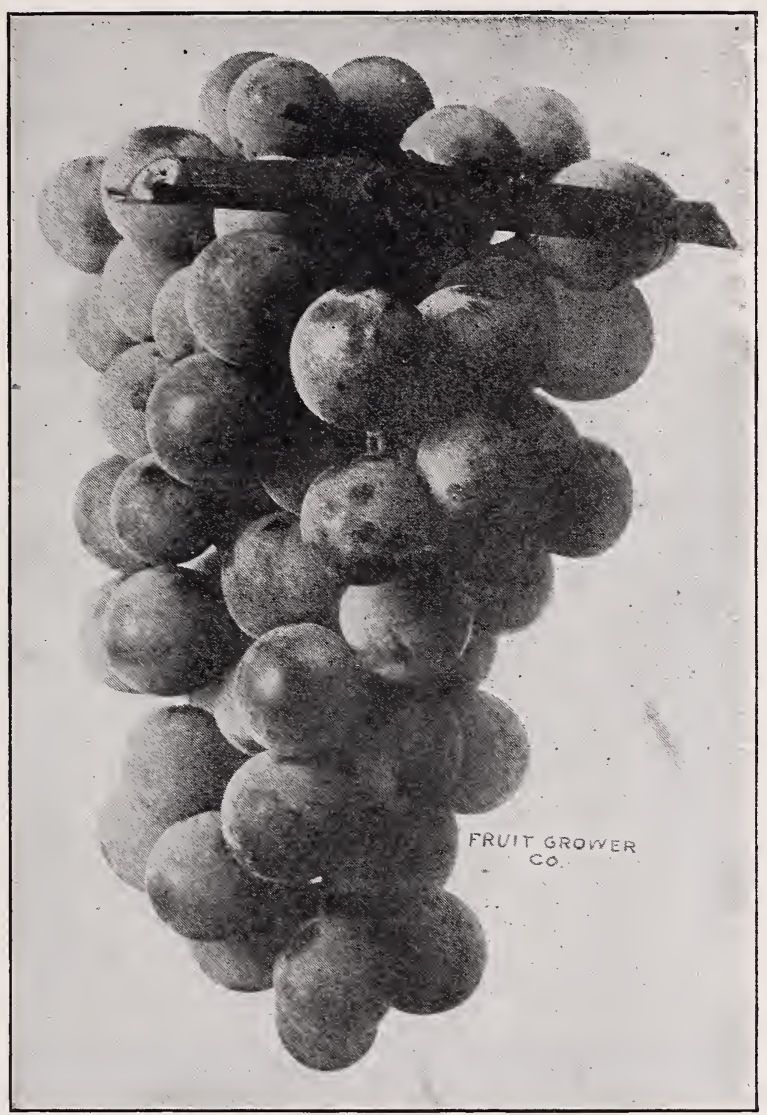

Concord.

\section{RED RASPBERRIES}

$\$ 3.00$ per 100 .

$\$ 10.00$ per 1000 .

ANTWERP-Large and firm, flavor not as fine as Cuthbert.

CUTHBERT-Old reliable sort, medium size, fine flavor, sweet.

\section{NEW! NEW!}

SUPERLATIVE-New English variety, berries very large, firm, excellent in quality, best shipper of all berries; after a few years nobody will plant any other variety. Price-25c each; $\$ 2.00$ per dozen; $\$ 10.00$ per 100 . 


\section{BLACK RASPBERRIES}

(BLACK CAPS)

$\$ 5.00$ per 100 .

$\$ 20.00$ per 1000 .

COLUMBIAN-Iarge, dark red-purple, very productive and vigorous, heavy grower.

CUMBERLAND-Hardy and productive, hig glossy berries, good shipper.

GREGG-Large, black and very productive.

KANSAS-Strong, vigorous growers, standing extremes of drought and cold, and bearing immense crops. Early, ripening just after Palmer. Berries size of Gregg; of better color; jet black and almost free from bloom; firm, of best quality; presents a handsome appearance and brings highest price in market.

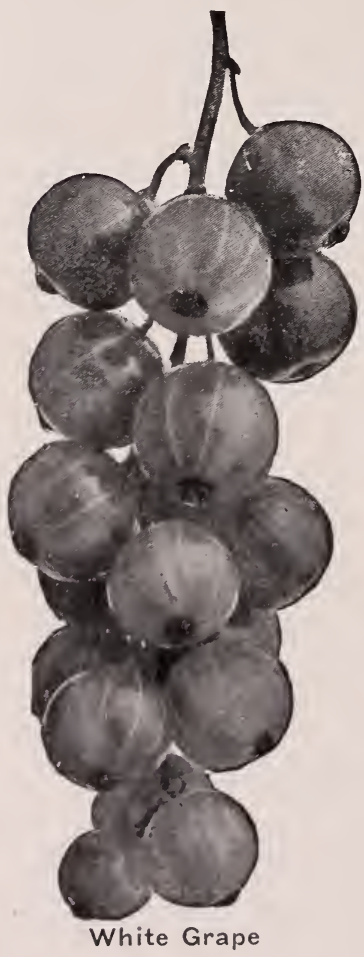

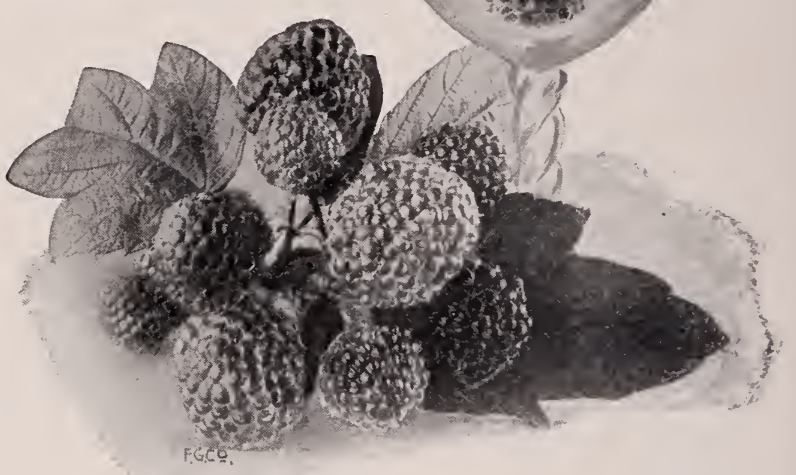

Cumberland

\section{GURRANTS}

$10 \mathrm{c}$ each.

FAY'S PROLIFIC (Red)-Originated in Chautauqua County, N. Y. A cross between Cherry and Victoria. Of large size, fine flavor, and claimed to be twice as prolific as the Cherry. Universally commended by those who have had experience with it.

RED DUTCH-An old well known sort. Medium size, good quality and very productive.

VICTORIA (Red)-A splendid variety, ripening two or three weeks later than the others, and continuing in fine condition for a long period. Bunches extremely long; berries of medium size; brilliant red and of the highest quality.

WHITE GFAPE-Very large; yellowish-white; sweet, or very mild acid; excellent quality and valuable for the table. The finest of the white sorts. Very distinct from White Dutch, having a low, spreading habit, and dark green foliage. Very productive. NAPLES (Black)-Large, rich and tender, excellent for jellies and wine. 


\section{BLACKBERRIES}

$8 \mathrm{c}$ each; $\$ 6.00$ per 100.

BLACK NO. 1-Largest, hardiest and most profitable.

SNYDER-The old standard, known to all.

EARLY HARVEST-Good, old, early sort.

HIMALAYA GIANT-Vigorous grower, canes sometimes reach 30 to 40 feet and must be trained on a trellis; fruit large, black; very abundant bearer and excellent shipper, shape more round than Kittatinny or Lawton, more juicy and smaller seed. Mr. Brodie, superintendent experimental station, Puyallup, states that it has yielded at the rate of 400 crates $(9,600$ quarts) per acre, arıd thinks it might be made to yield 600 crates per acre on proper soil. Price-12c each; $\$ 10$ per 100.

MAMMOTH-This is a rampant grower, and is unlike any other blackberry plant, as it trails on the ground, and under favorable conditions will grow twenty feet in a season. It is enormously productive and exceedingly early, ripening three weeks before other cultivated kinds. Fruit very large, specimens measuring two and $a$ half inches long; seeds small, soft and abundant; core small and soft; in size and flavor said to surpass all other varieties of blackberries. Price-12c each; $\$ 10$ per 100 .

\section{OREGON EVERGREEN}

- A strong - growing late variety of trailing or climbing habit; retains its foliage through the winter: a

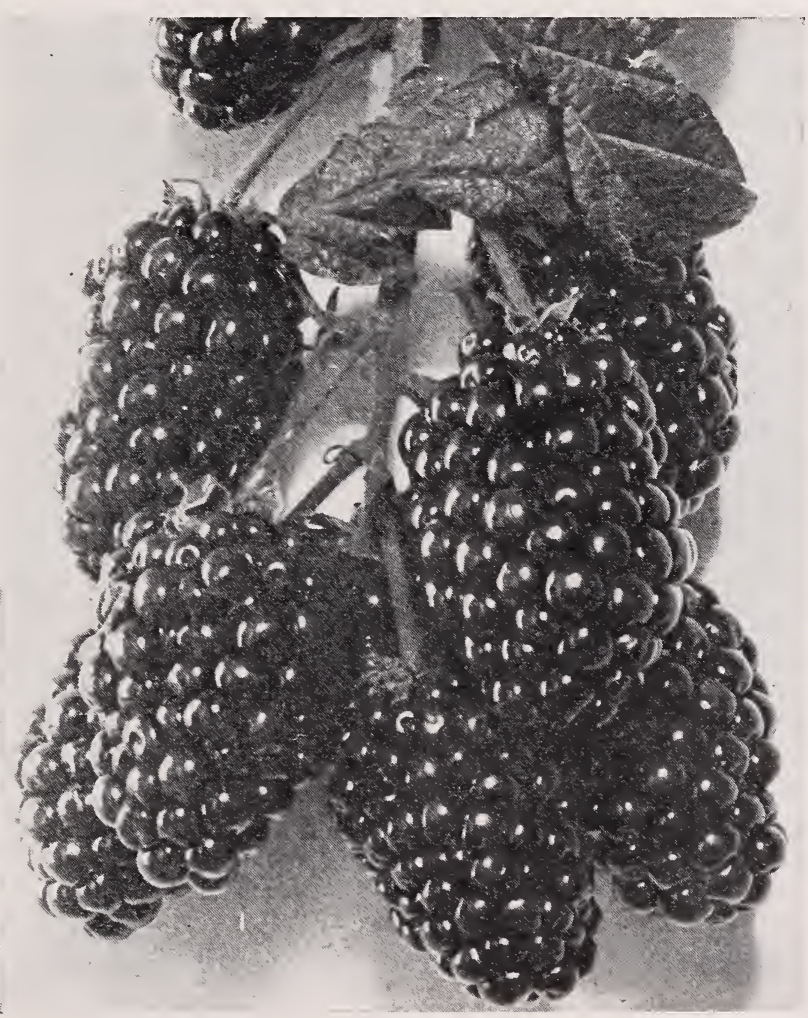

Early Harvest

heavy producer of good sized blackberries. Price-12c each; $\$ 10$ per 100 .

LOGAN BERRY-This berry is thought to be a cross between the blackberry and raspberry; the fruit is as large as the largest blackberry, but is of a bright red color when fully ripe; it combines the color of the blackberry and the raspberry; it ripens early and is a good shipper; the canes are strong but trail on the ground like the dewberry, and are free from thorns, but have fine spines like the raspberry. Price-15c each; $\$ 10$ per 100. 


\section{BLACKBERRIES-Continued}

PHENOMENAL BERRY--This is said to be the most valuable of Luther Burbank's novelties. It is a cross between the Improved California Dewberry and the Cuthbert Raspberry. Mr. Burbank describes it as larger than the largest berry ever before known; bright crimson raspberry color; productive as could be desired and the most delicious of all berries for canning and drying. The berries grow in clusters, each having five to ten or more berries, often measuring three inches around one way by four the other. Price-25c each; $\$ 15$ per 100 .

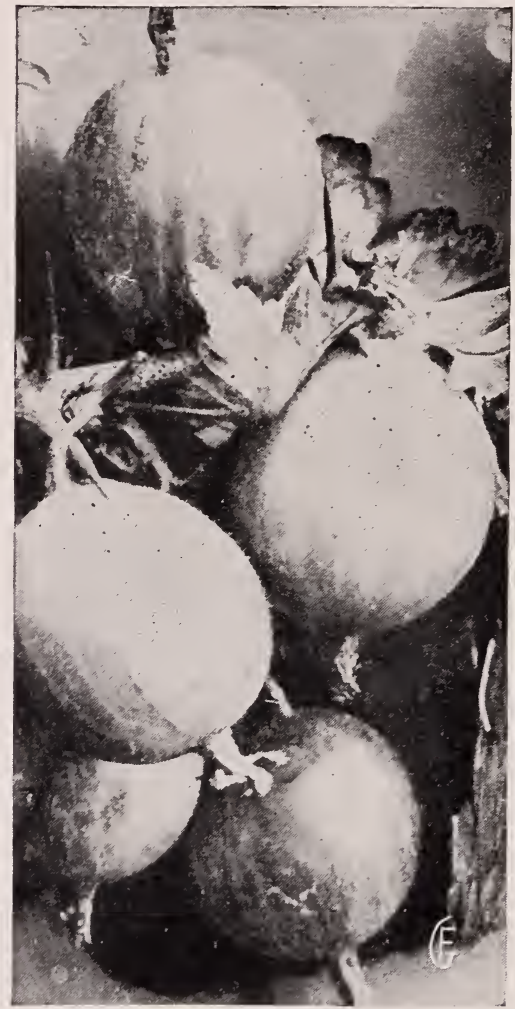

Downing.

\section{DEWBERRIES}

LUCRETIA-A low-growing trailing blackberry of large size and best quality; hardy, healthy and very productive of fruit that ripens before other blackberries, and is often more than an inch and a half long by an inch in diameter and entirely free from the hard core common to blackberries. Price-- $\$ 6.50$ per 100 .

\section{GOOSEBERRIES}

$10 \mathrm{c}$ each.

DOWNING-Twice as large as Houghton, excellent.

INDUSTRY-Large, oval, dark red.

OREGON CHAMPION-Fruit large, round, immense bearer; one of the best.

\section{STRAWBERRIES}

\author{
$\$ 8.00$ per 1,000 .
}

AROMA (S)-Season very late; size much above medium; bright red flesh to center and a good shipper. One of the best pollenizers for late sorts; well adapted to light soil and will not disappoint you.

BRANDYWINE-One of the most popular berries on the market. Berries are very large, deep red to center, firm and a good shipping fruit; stems are stout and short, holding the fruit well up from the ground; succeeds in any strong soil or sandy moor. Price-25c per dozen; 50c per $100 ; \$ 3.00$ per 1,000 .

BUBACH'S NO. 5-One authority says: “The great strawberry the horticulturists have been seeking and the millions waiting for has been found-Bubach's No. 5-the best out of 500 new seedling varieties. Very prolific, of excellent flavor, sweet sub-acid, and in size simply immense, berries averaging large; many over $21 / 2$ inches in diameter and 7 inches in circumference. Its equal has not been produced on this continent." Another says: "Lxceeds all others in size, quality and productiveness."

CLYDE (S)-Season medium. It has been many years since a berry has been introduced which created such a furore among growers as this. Its strong points may be enumerated as follows: Enormously productive, berries large, coneshaped, as pretty as a top, bright crimson to the center, and seems to succeed on all soils. By all means give this berry a trial. 


\section{STRAWBERRIES-Continued}

EVERBEARING-Berries medium, good flavor, prolific bearer. Bears from beginning of season until freezing.

GANDY'S PRIZE (S)-One of the most popular extra late sorts. The berries are large, cone-shaped and as even as a top, and perhaps as largely planted as any late variety. It is very productive, considering it ripens its berries nearly all at once and after most other varieties are running small, so the grower is still able to supply his customers with fine large berries.

GLEN MARY (S)-This is becoming a great favorite; big, deep red, rich, meaty berries.

HAVERLAND (P) - This is a berry that is immensely productive everywhere. Medium in season, fruit large, light in color, needs near market, but for home garden nothing excels it in amount of fruit.

JESSIE-Berries large, handscme, dark red; plant is vigorous, healthy, with strongly staminate blooms and a pollenizer for imperfect flowered fruits.

HOOD RIVER (Clark's Seedling)-Originated at Hood River, Oregon, where it is planted to the exclusion of all others for long distance shipments; large, round and smooth; color a beautiful dark red, and in quality is unsurpassed. Ripens early.

MAGOON-This new berry was originated near Portland, Oregon, and promises to be one of the leading berries in the Northwest. A good shipping and canning variety. Ripens about ten days later than Hood River.

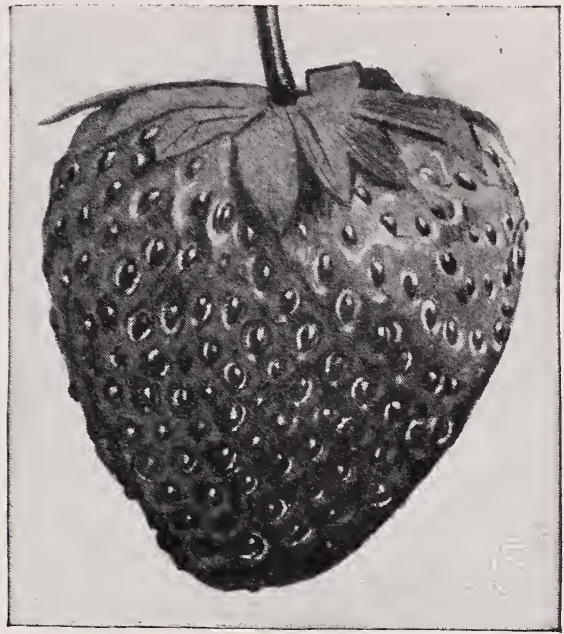

Hood River-(Clark's Seedling)

JOHNSON'S EARLY-Especially valuable on sandy land, being more generally. planted on such soil than on any other; it roots deep and stands the drouth well; berries are medium in size, but will hold up to the last picking and look nice in the box; color a crimson red to the center; firm and a good shipper.

LOVETT'S-A popular, attractive red berry; above medium in size, and delicious in flavor; succeeds on all soils.

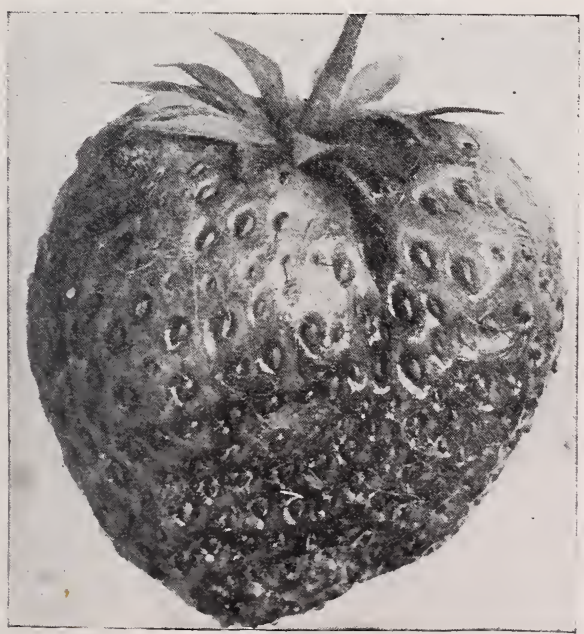

Senator Dunlap (See page 20)
MARSHALL-Berries very large, handsome, rightly flavored, of excellent quality; with high culture the strong, healthy plants produce great crops. Early and a most valuable market sort.

MICHEL'S EARLY-Berry deep red to center; medium size; a good shipper; foliage bright green; grows on sandy or loamy soil.

NEW YORK-Very large, bright red. strong foliage and very heavy fruiter; should have strong, rich soil.

NICK OHMER-A fancy market berry and superb for the table; a giant in size; deep red all through, globular, high flavored and delicious; in healthy vigor and fruitfulness unsurpassed by any other sort.

ROUGH RIDER-One of the latest berries of the largest size; bright red. firm; highly recommended for rich soil. It sometimes fails on light sandy soil; good berry for the late markets. 


\section{STRAWBERRIES-Continued}

SAMPLE-A strong plant that succeeds well on nearly all soils; large, fine berries; pointed, conical, rich scarlet; firm and of good quality. A money maker for the market.

SENATOR DUNLAP (P) - This is an all round, rough and ready producer. The plant is sturdy, and it yields heavy crops of best quality berries. With its clean, healthy foliage it has no tendency to rust. The berries are very large, roundish conical, regular, with slight neck. They are glossy crimson in color, with the meat firm and solid, deep crimson throughout. It will not disappoint the grower. Indeed, it has proved itself to be a better berry than it was thought to be by those who had not fruit it before. It is far better than Warfield, which it resembles somewhat. It should be extensively planted, as it occupies a place among the best.

SHARPLESS-Very popular and probably more extensively cultivated than any other variety; fruit large, bright scarlet; flesh light red, moderately firm, sweet and of good flavor; very valuable for home and market use.

SPLENDID (S)--Above medium size, dark crimson, very productive and handles well; is said to have out-yielded Warfield. If we were going to select just one variety from our list to plant exclusively, it would be splendid. It is the most satisfactory berry we have ever planted. It is very uniform in shape and size, dark crimson color all over and best in quality of any berry on our list. Makes plants freely, and they have abundance of bright, healthy foliage, never having shown a trace of disease.

UNCLE JIM-Plant is large and healthy, with abundant foliage. Berries large, very uniform, handsome and attractive. Perfect blossom.

WARFIELD (P) - This has succeeded everywhere and with everybody. Sells well and ships well; bears immense crops of dark blood red berries. One of the very best for canning. Don't fail to plant some of this variety.

WILLIAM BELT-Very popular on heavy, rich land; berries are of the very largest and their bright color makes them great sellers; grow in hills or hedge rows for best results.

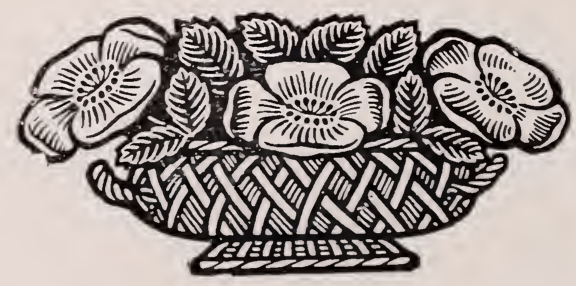




\section{ORNAMENTAL DEPARTMENT}

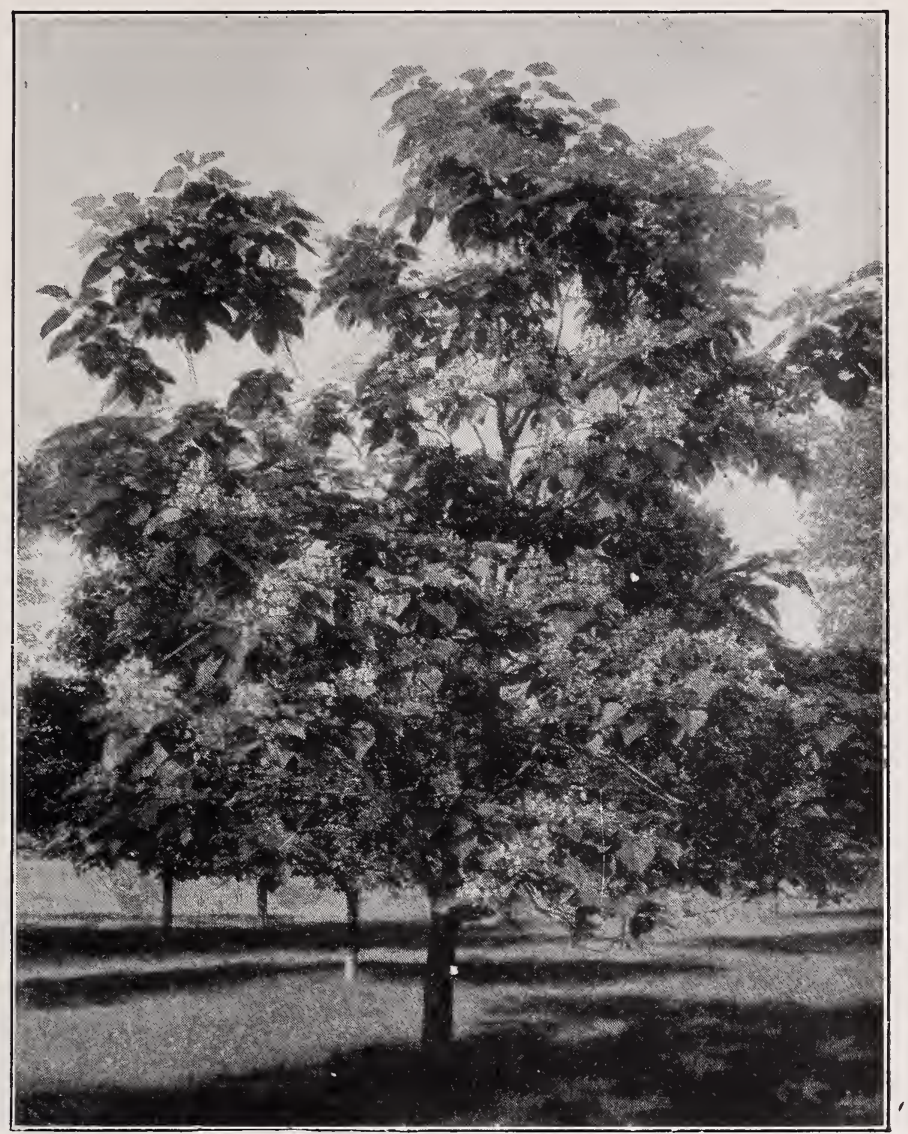

Catalpa Speciosa.

\section{SHADE AND ORNAMENTAL TREES}

MOUNTAIN ASH (American)--A fine ornamental tree, with bright scarlet berries. Six feet, $60 \mathrm{c}$ each.

MOUNTAIN ASH (European)-A fine hardy tree; head dense and regular, covered from July till winter with great clusters of bright red berries. Six feet, 60c each.

WHITE ASH-A beautiful shade tree. Grows successfully in the most northern parts. The wood is very valuable. Five to six feet, $40 \mathrm{c}$ each.

CATALPA SPECIOSA-A very hardy tree with large, tropical appearing foliage, and a free bloomer, followed by long bean-like pods. Desirable for shade and stręet trees. Six to eight feet, $60 \mathrm{c}$ each.

ELM, AMERICAN WHITE-A noble, drooping, spreading tree of our own woods; one of the grandest for park and street. Six to eight feet, 40c each. 
SHADE AND ORNAMENTAL TREES-Continued

EUROPEAN WHITE BIRCH-A rapid growing shade tree of beautiful form. Very desirable for street or lawn planting. By the time the tree is five or six years old the bark of the trunk and larger branches becomes a beautiful silvery white color. Entirely hardy in all parts of the Northwest. Makes elegant shade. Six to seven feet, $35 \mathrm{c}$ each.

HORSE CHESTNUT (Red Flowering) - Not so rapid or as fine a grower as the White; foliage of deep green and blossoms later with showy red flowers. Four to five feet, $60 \mathrm{c}$ each.

HORSE CHESTNUT (White Flowering)-A very beautiful well-known tree, with round, dense head, dark green foliage and an abundance of showy flowers in early spring. Readily transplanted, hardy, and succeeds well on a variety of soils. Four to five feet, $60 \mathrm{c}$ each.

LABURNUM, GOLDEN CHAIN-Bears long, pendant racemes of yellow flow ers in June; showy and beautiful. Should be in every lawn. Five to six feet, $50 \mathrm{c}$ each.

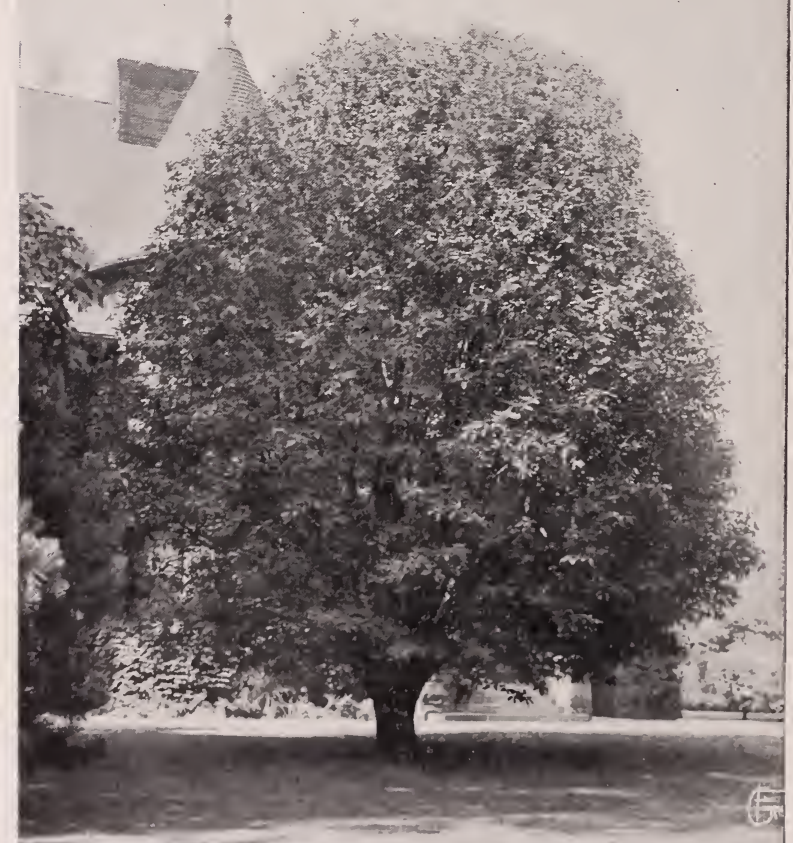

Mountain Ash (See page 21.)

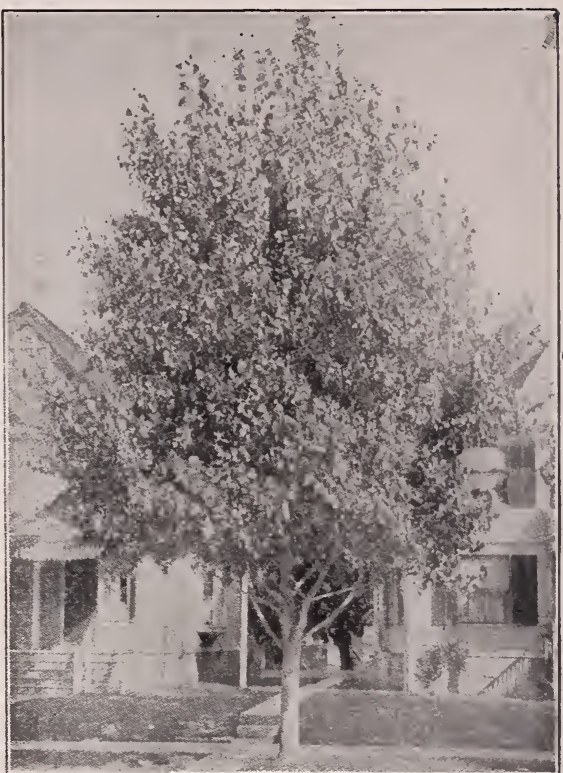

Carolina Poplar.

BLACK LOCUST-A very rapid growing tree, covered in June with sweetscented, white flowers; valuable as a shade tree and also for its hard wood. Five to six feet, $25 \mathrm{c}$ each.

LINDEN (Commonly called Basswood) - A ver y graceful and beautiful tree for planting on the lawn. Its leaves are moved with the least breath of air and show the white surface underneath. Its blossoms are delightfully fragrant, and the busy bee delights in their sweetness. Seven to eight feet, Soc each.

M A P LE, WEIR'S CUT. LEAVED-A variety with cut or dissected foliage; branches slender and drooping, almost as graceful as the cut-leaved birch. The foliage is silver underneath. Six to eight feet, $90 \mathrm{c}$ each.

NORWAY MAPLE-A handsome tree of large growth, forming a wide, 


\section{SHADE AND ORNAMENTAL TREES-Continued}

round head of spreading branches and having broad, deep green leaves. Strong, compact and vigorous. One of the very best trees for street, park or lawn. Five to six feet, $40 \mathrm{c}$ each.

MAPLE, ASH LEAF (Manitoba Box Elder)-A durable tree; transplants well and grows rapidly, producing considerable shade in a very short time; most used in the West and Northwest, as it withstands successfully both drouth and extreme cold. It attains a height of 70 feet. Succeeds in various soils. Five to six feet, $40 \mathrm{c}$ each.

MAPLE, SILVER OR SOFT-A magnificent shade and ornamental tree of rapid growth. It is perfectly hardy and will thrive in any locality. The leaves are beautifully shaped and have a silver gleam. Five to six feet, $35 \mathrm{c}$ each.

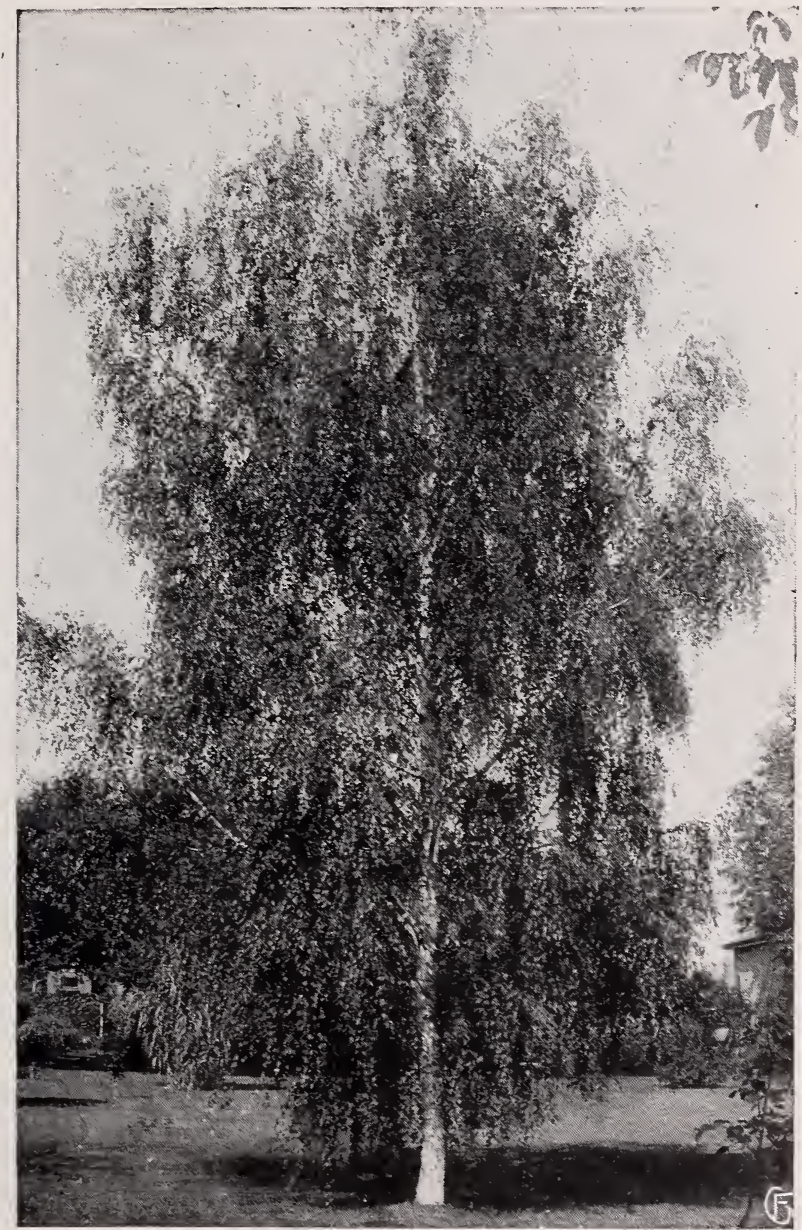

Cut-Leaved Weeping Birch

SYCAMORE-A handsome, broad spreading tree, with large, thick, dark greer: leaves. It is a rapid grower and hardy. Five to six feet, $40 \mathrm{c}$ each.

CAROLINA POPLAR-Pyramidal form and robust growth; leaves large, glossy, serrated, of light green color, changing to dark green. Makes a very handsome shade or street tree. Smoke and soot of large cities do not damage its foliage. Perfectly hardy. Five to six feet, $30 \mathrm{c}$ each. 


\section{SHADE AND ORNAMENTAL TREES-Continued}

POPLAR, LOMBARDY-This is of obelisk form and grows rapidly. It is planted largely everywhere as it forms a striking feature of any landscape. It is perfectly hardy. Five to six feet, $30 \mathrm{c}$ each.

POPLAR, BALSAM (Balm of Gilead)-A handsome native, with dark, ovate leaves, silvery beneath. The spice of the buds is used medicinally. Five to six feet, $30 \mathrm{c}$ each.

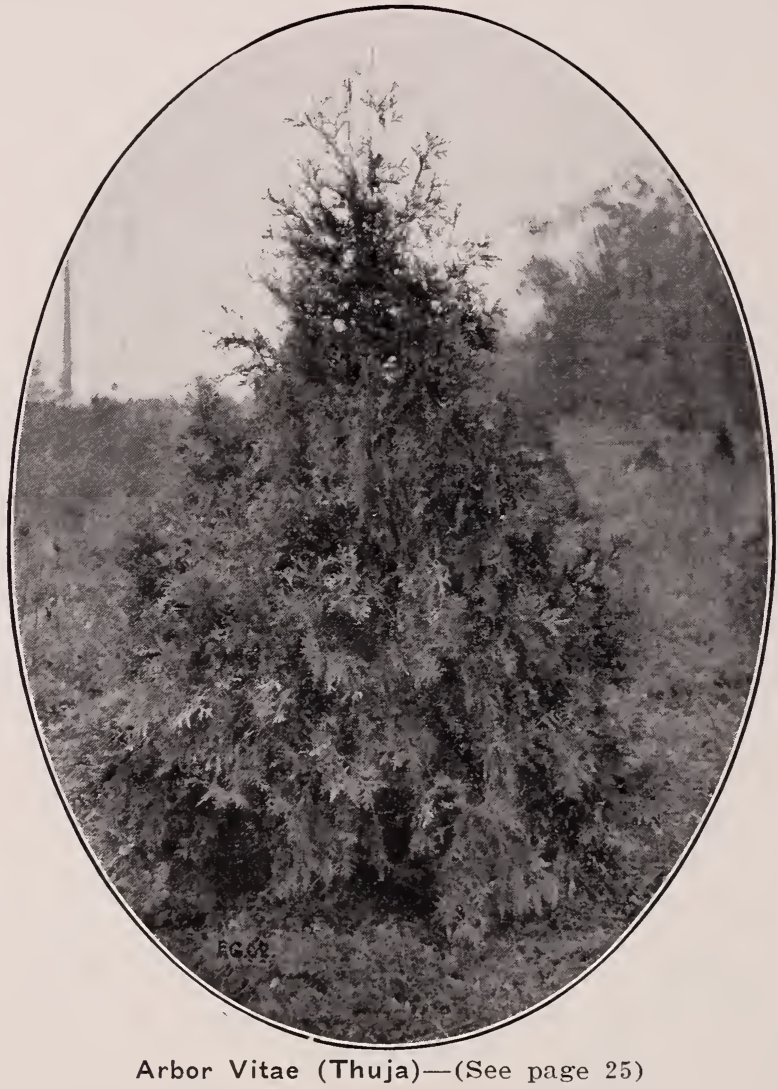

\section{WEEPING TREES}

BIRCH, CUT-LEAVED WEEPING-One of the most elegant of all weeping trees. Its tall, slender, yet vigorous growth, graceful drooping habit, silvery white bark and delicately cut foliage present a combination of attractive characteristics rarely met with in a single tree. Six feet, $\$ 1.25$ each.

ELM, CAMPERDOWN WEEPING-Grafted six to eight feet high, this torms the most picturesque of drooping trees. The leaves are large, dark green and glossy. $\$ 1.25$ each.

WILLOW, BABYLONIAN-Weeping willow. Tall, graceful and drooping; very beautiful. Six feet, $\$ 1.00$ each.

WILLOW, KILMARNOCK-A graceful weeping tree, with glossy green foliage. Two years, $\$ 1.10$ each. 


\section{EVERGREENS}

ARBOR VITAE (Thuja)-American (Occidentalis)-This is one of the very finest evergreens for hedges. It is very hardy, and if set at the proper time, with care and without undue exposure, it may be relied upon to live, but small plants 12 to 18 inches high, which have been transplanted several times, are preferable. It bears shearing better than any other variety, and may be made a very beautiful and dense hedge or screen to divide grounds, or for any purpose where it is not required to resist cattle or other animals. Price, 50c each.

FIR, BALSAM OR SILVER-Leaves dark green above, silvery beneath, retaining: their color during the severest winter; grows rapidly and is very hardy. Price, $50 \mathrm{c}$ each.

SCOTCH PINE-The toughest and hardiest of pines. Foliage more silvery than Austrian. Desirable for mass and shelter. Price, $75 \mathrm{c}$ each.

JUNIPER (Juniperus)-Irish (Hibernia)-Very erect and tapering in its growth, forming a column of deep green foliage, a pretty little tree or shrub, and for its beauty and hardiness is a general favorite. Price, $75 \mathrm{c}$ each.

JUNIPER, NORWAY (Excelsa)-A lofty, elegant tree of perfect, pyramidal habit, remarkably elegant and rich, and as it gets age, has fine, very graceful pendulous branches; it is exceedingly picturesque and beautiful. Very popular, and deservedly so, and should be largely planted. One of the best evergreens for hedges. Price. $75 \mathrm{c}$ each.

CALIFORNIA PRIVET (Ligustrum Ovalifolium) - This is the most glossy-leaved and rapid-growing of all the half-evergreen plants used. for low hedges around private lawns and is the universal favorite. Price, $\$ 5.00$ per 100 .

\section{CYPRESS (Lawsonia) - A} fine evergreen, native of the

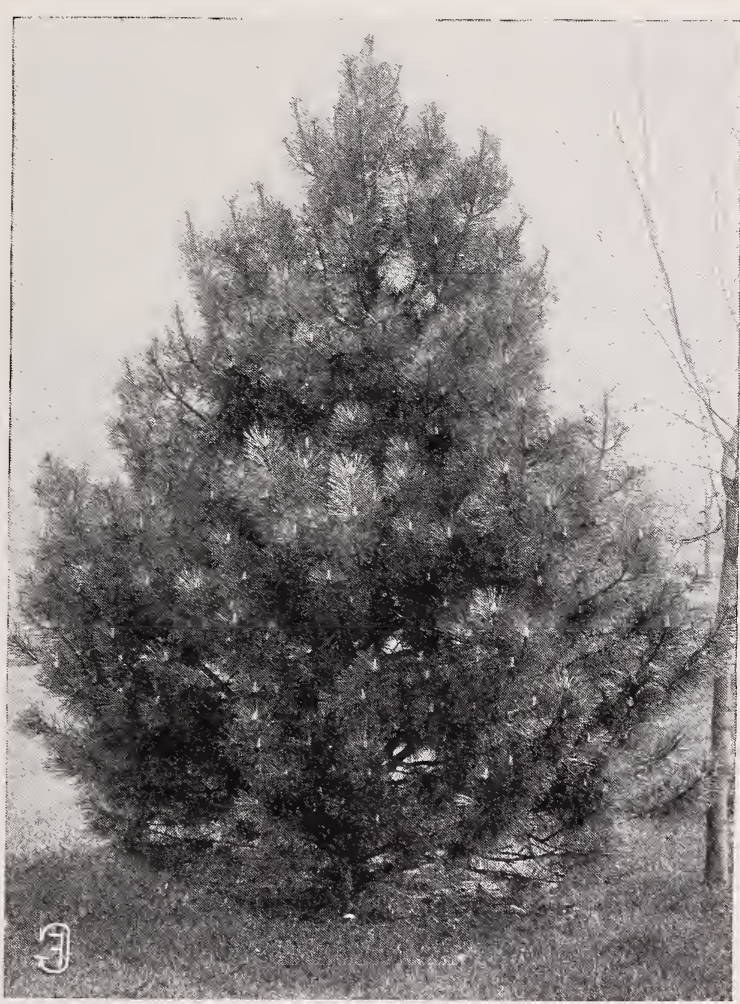

Scotch Pine Pacific Coast. One of the most graceful and beautiful of evergreens; of fine, compact habit; delicate feathery, vivid green foliage. Price, $60 \mathrm{c}$ each.

RED CEDAR-A well known American tree, with deep green foliage. Can be trained in any form and makes a fine ornamental tree. Price, 75c each.

SPRUCE, NORWAY-A lofty, elegant tree, of perfect, pyramidal habit, remarkably elegant and rich, and as it gets age, has fine, graceful pendulous branches. It is exceedingly picturesque and beautiful. Very popular and should be largely planted. Price $60 \mathrm{c}$ each. 


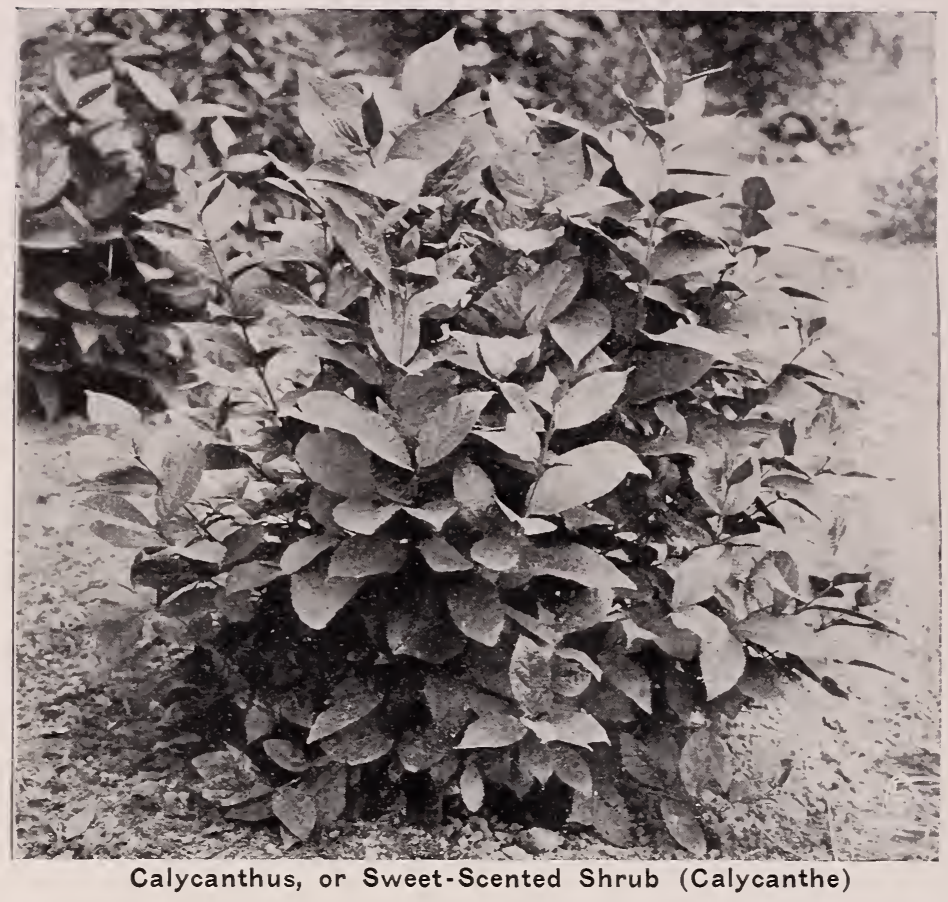

\section{FLOWERING SHRUBS}

ALTHEA, OR ROSE OF SHARON (Hibiscus)-The altheas are fine, free-growing flowering shrubs of very easy cultivation. Desirable on account of flowering in August and September. Price, 40c each.

CALYCANTHUS, OR SWEET-SCENTED SHRUB (Calycanthe)-The wood is fragrant, foliage rich, flowers of rare chocolate color, having a peculiarly agreeable color. Price, $35 \mathrm{c}$ each.

DEUTZIA-This valuable species of plants comes to us from Japan. Their hardiness, luxuriant foliage and profusion of attractive flowers, render them deservedly among the most popular of flowering shrubs. Price, $40 \mathrm{c}$ each.

PURPLE FRINGE, OR SMOKE TREE-A very elegant and ornamental large shrub, with curious, hair-like flowers, which, being a pinkish brown color, give it. the names, "Purple Fringe" and "Smoke Tree." The blossoms appear in July, sometimes literally covering the tree and remaining all summer. Three to four feet, $40 \mathrm{c}$ each.

LILAC, WHITE-The common variety; cream-colored flowers. Price, $40 \mathrm{c}$ each.

LILAC, PURPLE-The well known old-fashioned lilac; bluish-purple flowers. Price, 40c each.

HYDRANGEA PANICULATA GRANDIFLORA-A fine, hardy shrub, growing to the height of eight or ten feet; flower white, in great pyramidal panicles a foot long. Price, $35 \mathrm{c}$ each.

HYDRANGEA PANICULATA GRANDIFLORA, TREE FORM-The alway's valuable Hydrangea Paniculata Grandiflora becomes still more handsome and desirable when grown in standard or tree shape. In this form the magnificent trusses of flowers show off much more effectively than on the low spreading bushes that are usually seen. It forms a symmetrical miniature tree that is extremely well adapted either for massing or planting singly. Price, $75 \mathrm{c}$ each. 


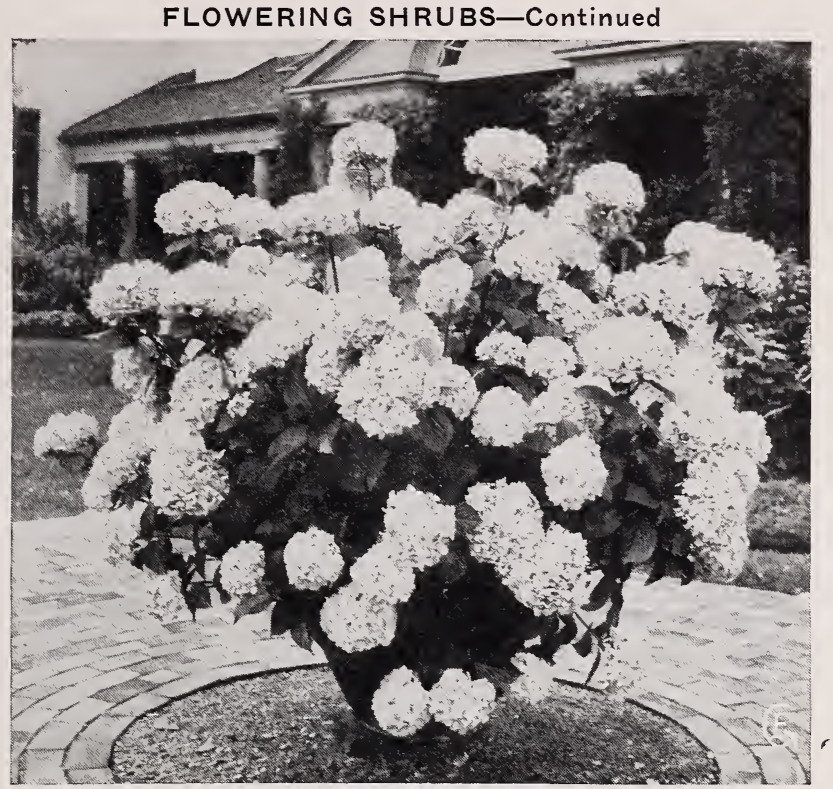

Hydrangea (See page 26)

SNOWBALL (Viburnum)-

Common (V. opulus) - A well known favorite shrub of large size, with globular clusters of pure white flowers in the latter part of May. Price, $40 \mathrm{c}$ each.

\section{SPIREA VAN HOUTTEI}

(S. Van Houttei) - The most showy of all the Spireas, and one of the very best flowering shrubs in cultivation. The plant is a rather tall, upright grower, with long, slender branches that droop gracefully with their weight of foliage and flowers. Flowers pure white, in great clusters and whorls, forming cylindrical plumes two or three feet long. This is one of the hardiest of al! the Spireas. Price, $35 \mathrm{c}$ each.

S YRINGA, GOLDEN LEAVED (P. Foliis Aureis)-A beautiful new variety with bright yellow foliage, which affords pretty contrasts with other shrubs, especially with the purple-leaved variet $y$. Price, $40 \mathrm{c}$ each.

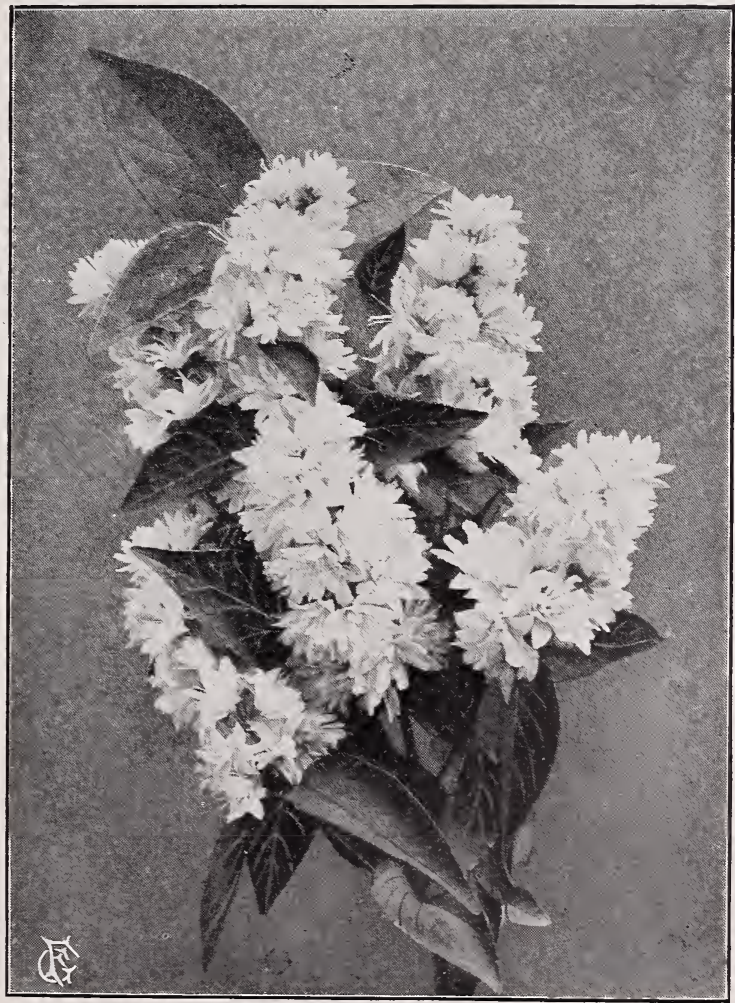

Deutzia (See page 26) 


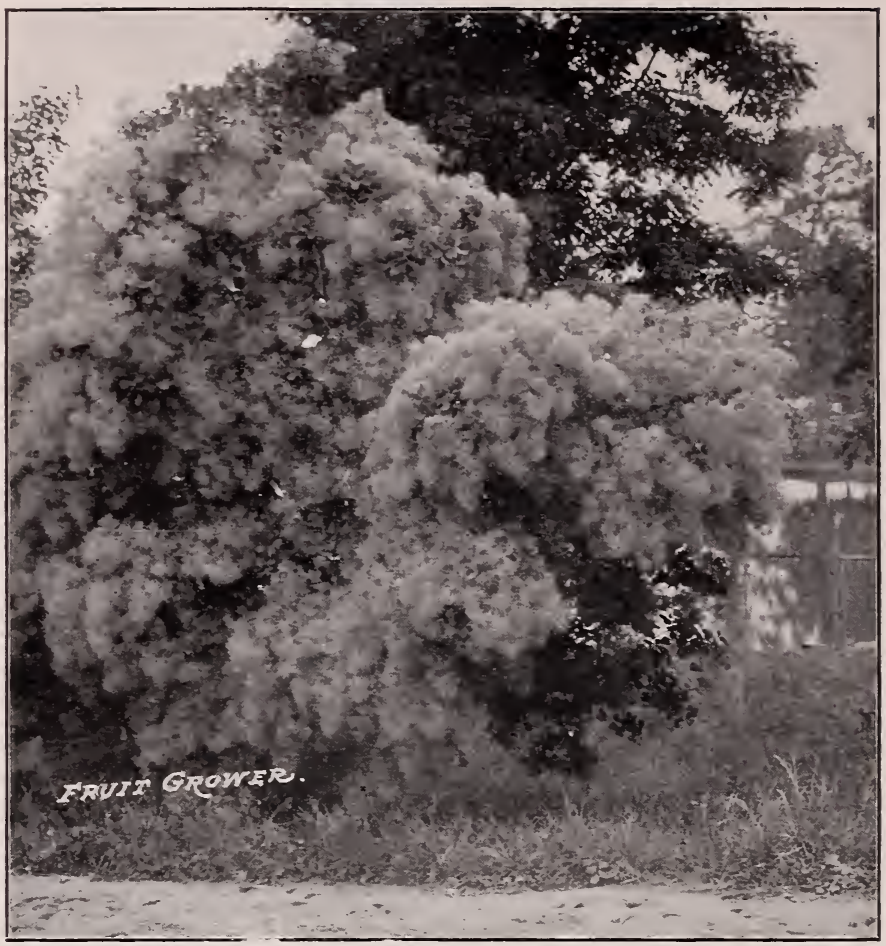

\section{FLOWERING SHRUBS- \\ Continued}

B E C H TEL'S F L O W ERING CRAB - Most beautiful of all the fine varieties of flowering crabs. At a dist ance the pretty medium sized tree seems to be covered with dainty little roses of a delicate $\mathrm{p}$ in $\mathrm{k}$ color. Blooms wh e n quite young. Is very fragrant; v e r y hardy. We place this at the head of the list for a beautiful sweet scented flowering small tree. Grows to 8 to 10 feet. Price, 50c each.

Purple Fringe, or Smoke Tree (See page 26)

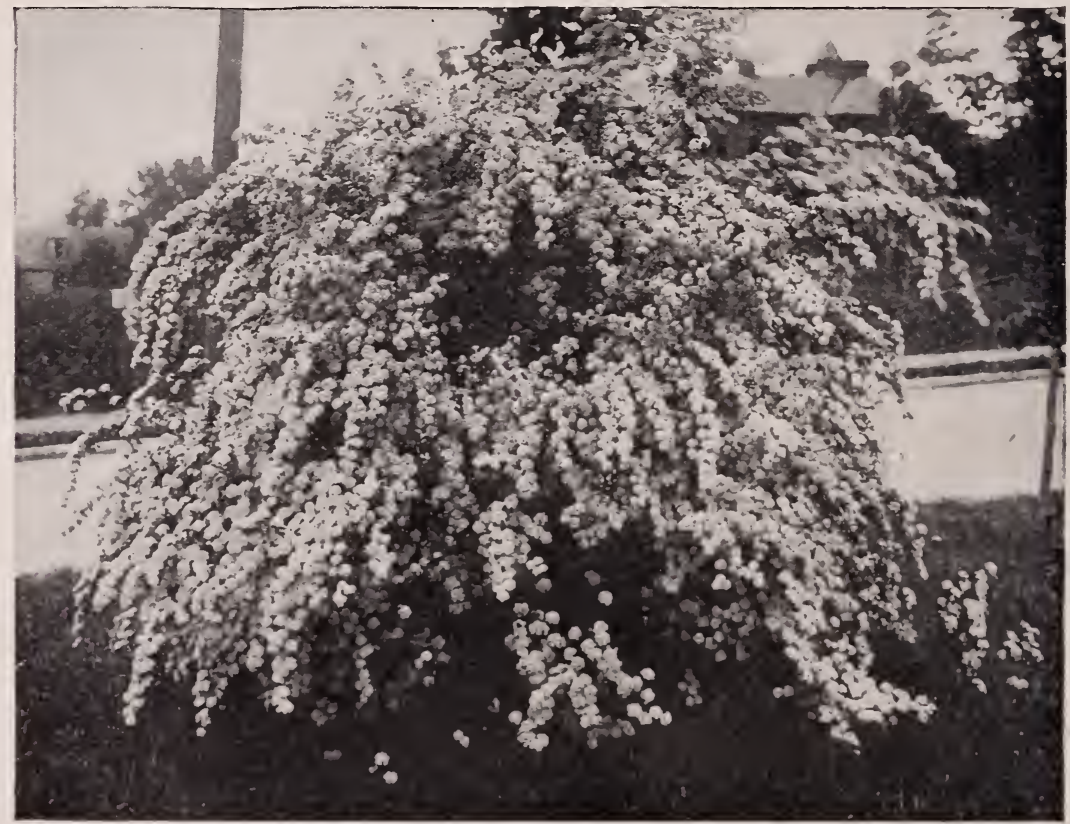

Spirea Van Houttei (See page 27) 


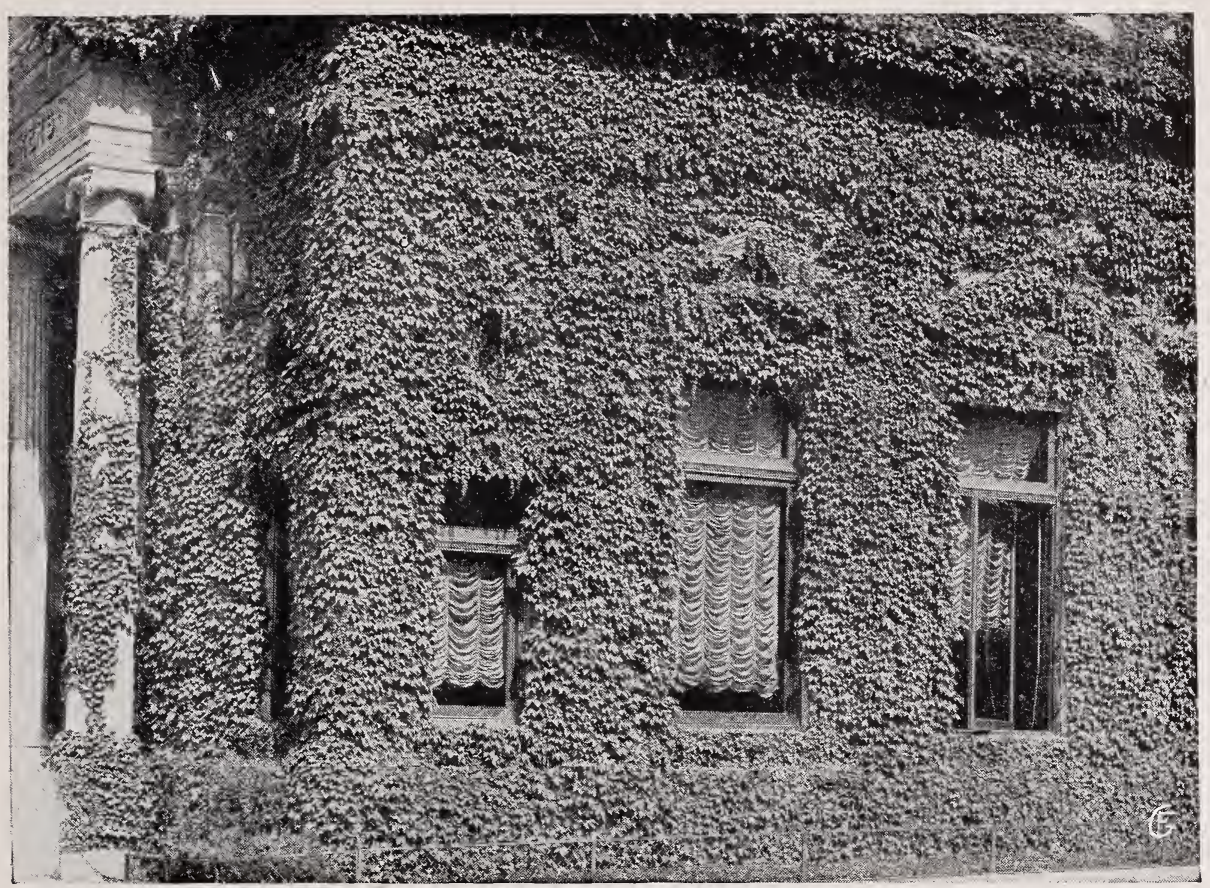

Ampelopsis Engelmani

\section{HARDY CLIMBING PLANTS}

HONEYSUCKLE, SCARLET TRUMPET-A strong, rapid grower, with beautiful scarlet trumpet-shaped flowers; blossoms nearly all summer; hardy. Each, 40c: 6 for $\$ 2.00$.

VIRGINIA CREEPER-A very rapid grower having very beautiful dark green foliage, which in autumn assumes the most brilliant hues. The vine is the best calculated in this country to take the place of English Ivy, and is in summer not inferior to it. One of the best climbing plants; hardy everywhere. Each, 30c; 6 for $\$ 1.50$.

AMPELOPSIS ENGELMANI-Similar to above only it clings to stone, brick, etc., with great tenacity. A rapid grower and hardy. Each, 30c; 6 for $\$ 1.50$.

CLEMATIS JACKMANII-This plant is a strong grower and an abundant bloomer from July to October. The flowers are large and of an intense violet purple color. Remarkable for their velvety richness. It has very few equals. Each, $65 \mathrm{c} ; 6$ for $\$ 3.00$.

CLEMATIS HENRYII-One of the largest perpetual hybrids, of robust habit and a free bloomer. Flowers large and a beautiful creamy white. From July to October; these two clematis are at their handsomest when planted side by side. Each $65 \mathrm{c} ; 6$ for $\$ 3.00$.

PANICULATA-A native of Japan. A beautiful and rapid growing climber, which in a very brief time will cover any ordinary veranda. The flowers are small, pure white and delightfully fragrant, and are borne in enormous masses, almost concealing the foliage. Entirely free from blight and regarded as a great acquisition. Each, $65 \mathrm{c} ; 6$ for $\$ 3.00$.

WISTARIA, W. SINENSIS (Chinese Wistaria)-One of the most rapid growing of all the climbing plants. Grows from 15 to 20 feet in a season. Has long, pendulous clusters of pale blue flowers in May or June and sometimes in autumn. $\$ 1.00$ each. 


\section{ROSES}

Two years old, $40 \mathrm{c}$ each.

AMERICAN BEAUTY-Color rich, rose crimson, shaded and veined in the most charming manner. Hardy, free bloomer and very desirable.

ANNE DE DIESBACH-Brilliant crimson, sometimes shaded with maroon; long pointed buds and large, finely formed flowers. Extra fine.

GENERAL JACQUEMINOT-Brilliant crimson; very large, globular and excellent; a free bloomer; unsurpassed in its clear, rich crimson, scarlet color.

PAUL NEYRON-Flowers of immense size, often five inches in diameter. Color deep clear rose, very fresh and pretty. The plant is a strong, healthy grower, with glossy foliage and is one of the most prolific bloomers in the Hybrid class; young plants in the nursery rows blooming almost without intermission from June to late October.

PR I NCE CAMILLE DE RO. HAN - V e r y dark. This rose is of a rich, velvety crimson, passing to an intense maroon shaded b l a ck, large, full flowers. One of the darkest roses and very handsome.

\section{ULRICH BRUN -} NER - Extra la rge, bold flowers, full and globular. Color $\mathrm{r}$ i c h, glowing c r i m s on, elegantly flamed with scarlet.

\section{HELEN GOULD} (Hybrid Tea)-. Free growing and vigorous for

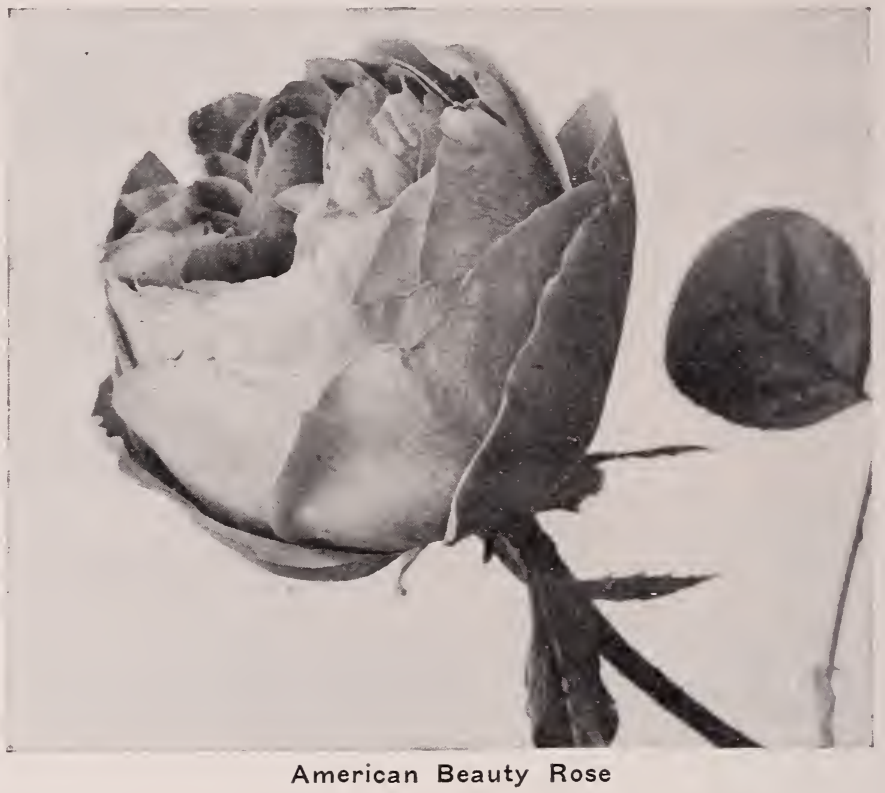

its color, it is remarkably constant in blooming, every newshoot producing a flower. The blooms are bright rosy carmine red, the buds are well formed, the fragrance is delightful, and taken altogether, it is a variety that should be generally planted.

ETOILE DE LYON-This magnificent Tea Rose is rich, golden-yellow; strong, healthy and vigorous grower. Immense bloomer, bearing flowers and buds early and late. Remarkably hardy with us.

MADAME CAROLINE TESTOUT (Hybrid Tea, Forcing) - A wonderful rose. The petals are large, and of elegant I,a France form; exquisitely edged and bordered with clear silver rose. Flowers and buds are extra large, color brilliant, satiny rose.

MAMAN COCHET (Tea)-This is our favorite rose. It is of the largest size, the flower is built up or rounded and very double, the color is a deep, rosy pink, the inner side of the petals being a silvery rose, shaded and touched with golden yellow. Very vigorous, deliciously fragrant.

MADAME ALFRED CARRIER-Flesh white and salmon yellow at base of petals. One of the best pillar roses. 


\section{ROSES-Continued}

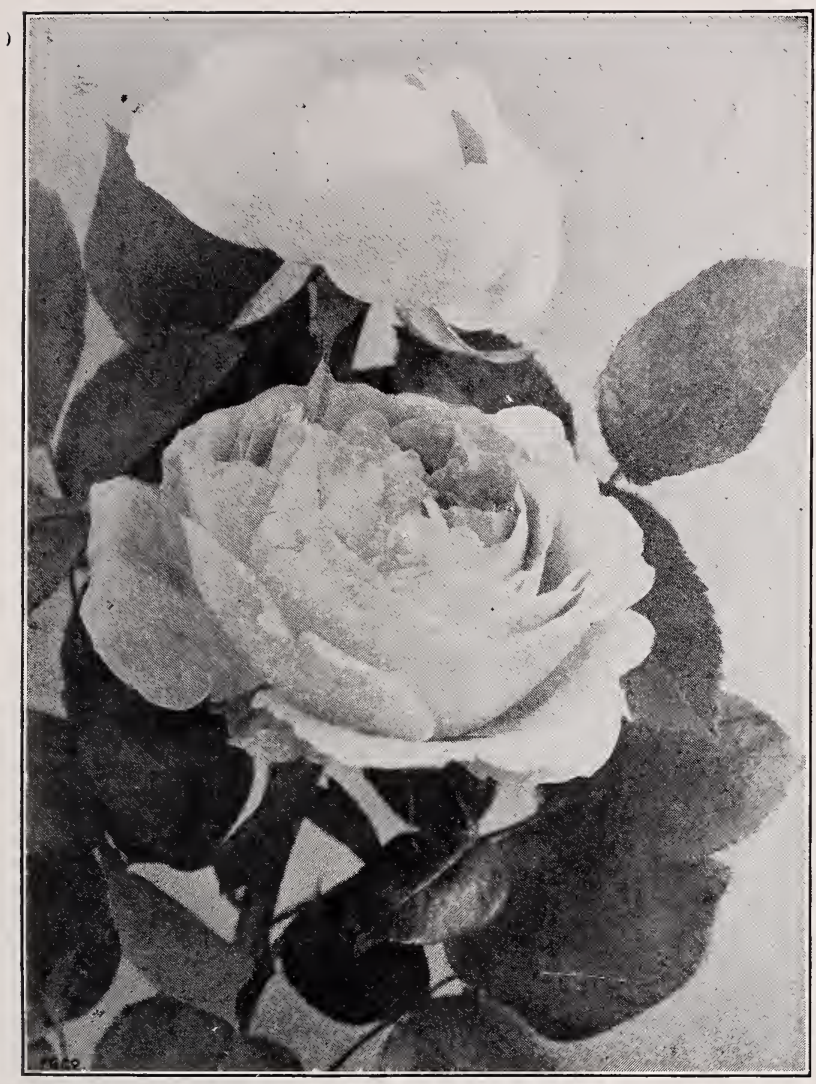

Paul Neyron (See page 30)
LA FRANCE (Hybrid Tea)- $\mathrm{P}$ e $\mathrm{r}$ a $\mathrm{ps}$ no rose is better known or more highly valued than La France. Both flowers and buds are of grand size. Color, a silvery rose, changing to pink. A general f a vorite and the sweetest of all roses.

WHITE LA FRANCE (Tea)-This magnifi cent rose is a pure white La France, having just a breath of rose-tinted blush, decidedly clouding the depths of its broad petals; the buds and flow ers are extra large, very full and finely formed; the fragrance is delicious.

FRAU KARL DRUSCH KI (Hybrid Tea)-Is undoubtedly one of the grandest hardy, pure-white roses ever introduced. $\mathrm{M}$ a $\mathrm{k}$ e $\mathrm{s}$ splendid buds and immense flowers; perfectly double and delightfully fragrant; large, thick petals; very $d u r a b l e$ and handsome; bright, shining green leaves, elegantly veined; a healthy, vigorous grower; and a constant and abundant bloomer. 'The most beauuful and satisfactory snow-white perpetual rose ever seen.

KAISERIN AUGUSTA VICTORIA-A beautiful rose, with elegant, large pointed buds and very large, full double flowers; color delicate creamy white; deliciously fragrant. The plant is a strong, healthy grower and constant bloomer, one of the choicest and most trustworthy garden roses.

PERSIAN YELLOW-Deep, bright yellow; small but handsome; double; a very early bloomer, and much the finest hardy yellow rose.

\section{CLIMBING ROSES}

CRIMSON RAMBLER-This is one of the most decided novelties in roses we have had for years. The plant is a vigorous grower, making shoots from eight to ten feet long in a season. A charming pillar rose; for covering trellises or buildings there is nothing finer. The flowers are grown to great pyramidal panicles, each carrying thirty to forty blooms; the individual flowers are one to one and onehalf inches in diameter and remain in perfect condition on the plants for a long time. The color is bright, vivid crimson, showing none of the purplish tint so commonly seen in crimson roses. 


\section{CLIMBING ROSES-Continued}

YELLOW RAMBLER--Flowers of medium size, in immense clusters, very sweet scented; a clear, decided yellow. The hardiest of all climbing roses; of a vigorous growth, often making a growth of ten to twelve feet in a season.

WHITE RAMBLER-Resembles Crimson Rambler in foliage and habit; flowers pure white.

BABY RAMBLER-This great novelty originated at Orleans, France, and is a hybrid produced by the crossing of Crimson Rambler and Glorie des Polyanthus. It preserves the prolific flowering quality of the latter, but with the color of the Crimson Rambler (clear brilliant ruby rose). The foliage is of a fine polished dark green, and is never attacked by insects or fungus. It blooms in clusters and is very continuous. The time of blooming of the first umbel is not ended when the adjacent branches are ready to open.

REINE MARIE HENRIETTE (T. Climbing)-Large, full, pointed bud; cherry red; often called the Red Gloire de Dijon.

GLOIRE DE DIJON-Noted for the great size of its flowers, its delicate tea scent. and its shades of color, being a blending of amber, carmine and cream. A magnificent climber.

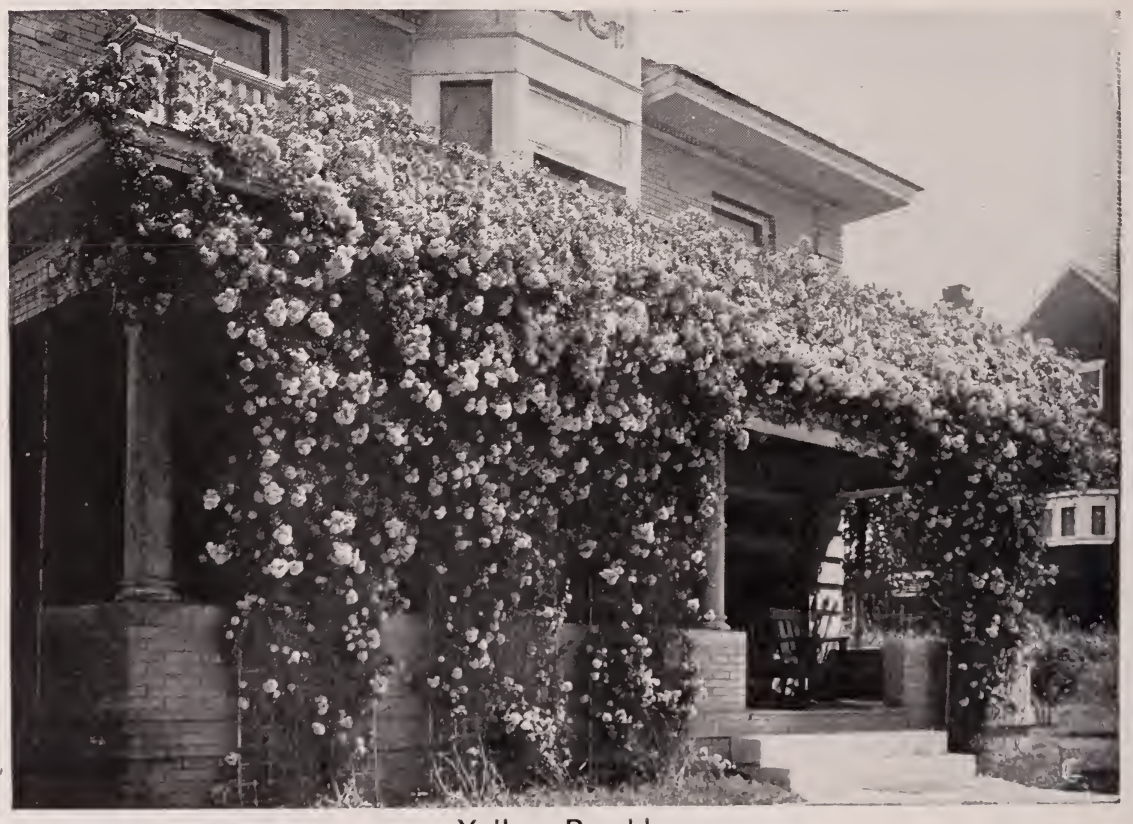

Yellow Rambler 


\section{Advice to Correspondents}

Please read the following articles before making out your orders:

1. All orders should be sent in as early as possible, as it is our rule to execute them in the order in which we receive them.

2. The names of every variety should be plainly written on the order sheet so as to prevent mistakes.

3. In case of lists of varieties we will fill out as near as possible, substituting with the next best variety in color and size with the correct label attached unless ordered not to do so.

4. We do not pay freight or express charges unless we have specially agreed to do so. If your station is a prepay point send money for freight charges to aroid delay and unnecessary correspondence.

5. C. O. D. orders will not be accepted unless accompanied by one-third the amount and the shipping point has an express agent.

6. All communications regarding varieties and prices not contained herein or any advice when desired will be cheerfully giren.

i. Where contracts are made to deliver trees at any particular place our responsibility ceases the day on which the purchasers are notified to receive their orders.

S. All trees are carefully labeled and packed in the best possible manner.

9. Our customers are requested to notify us immediately of any errors that may be committed in filling out their orders so we may at once make ample amends, as we desire to conduct our business in all respects satisfactorily to those who favor us with their orders.

\section{Guarantee of Genuineness}

10. Our trees are all budded or grafted from bearing trees, as far as possible, and every care and precaution is exercised to have them true to name; still, with all our caution, mistakes are liable to be made, but we hold ourselves in readiness, on proper proof, to replace all trees and other stock that may be untrue to label, free of charge, or to refund the amount paid. It is mutually understood and agreed to between purchasers and ourselves howerer, that our guarantee of genuineness shall in no case make us liable for any sum greater than that originally paid us for said trees, etc., that prove untrue.

11. We replace any trees which may fail to live, at half price, if trees have been planted and cared for properly, provided that we receive a specified list before September 1 st. 
